\title{
Archaeological Testing Associated with the Stabilization of Room 4 at Mission San Juan Capistrano, San Antonio, Bexar County, Texas
}

Jennifer L. Thompson

Follow this and additional works at: https://scholarworks.sfasu.edu/ita

Part of the American Material Culture Commons, Archaeological Anthropology Commons, Environmental Studies Commons, Other American Studies Commons, Other Arts and Humanities Commons, Other History of Art, Architecture, and Archaeology Commons, and the United States History Commons

Tell us how this article helped you.

This Article is brought to you for free and open access by the Center for Regional Heritage Research at SFA ScholarWorks. It has been accepted for inclusion in Index of Texas Archaeology: Open Access Gray Literature from the Lone Star State by an authorized editor of SFA ScholarWorks. For more information, please contact cdsscholarworks@sfasu.edu. 


\section{Archaeological Testing Associated with the Stabilization of Room 4 at Mission San Juan Capistrano, San Antonio, Bexar County, Texas}

\section{Creative Commons License}

\section{(c) (1) \&}

This work is licensed under a Creative Commons Attribution-NonCommercial 4.0 International License 


\section{Archaeological Testing Associated with the Stabilization of Room 4 at Mission San Juan Capistrano, San Antonio, Bexar County, Texas}

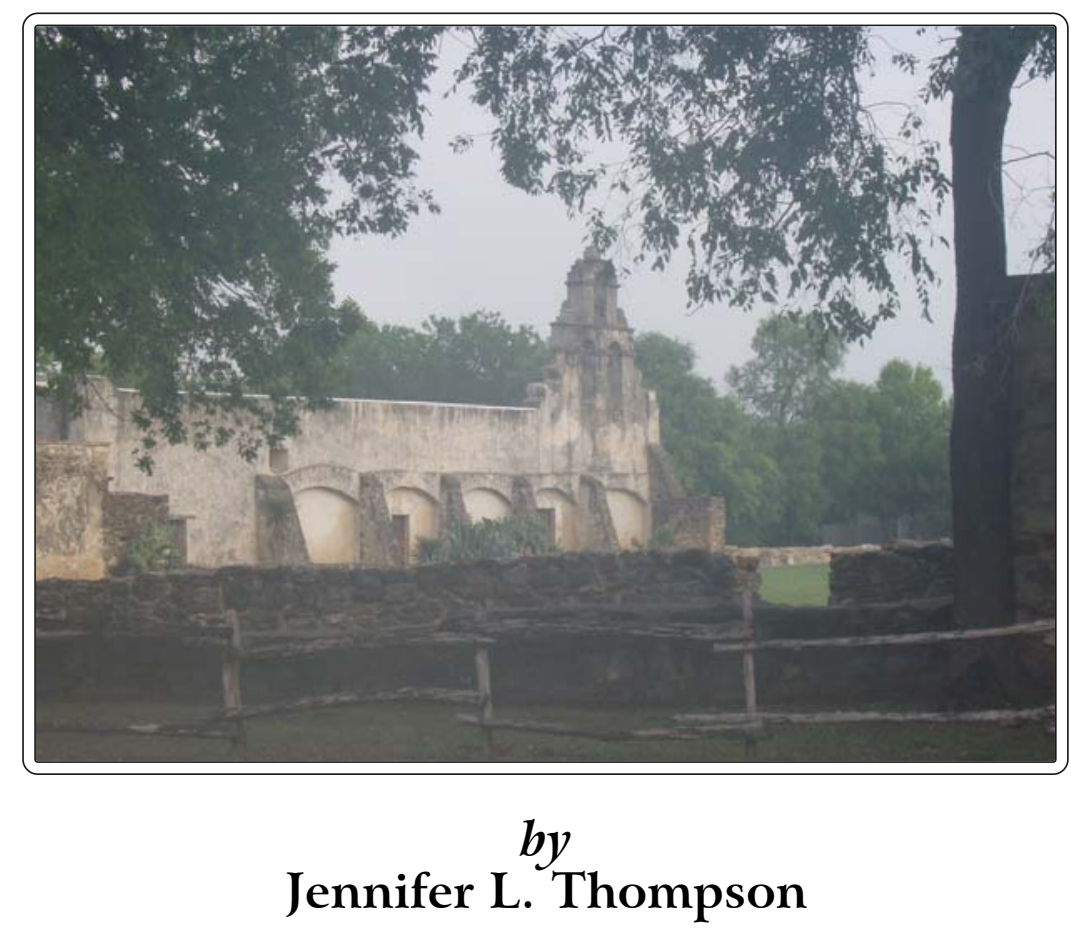

with contributions by

Barbara A. Meissner and Kristi M. Ulrich

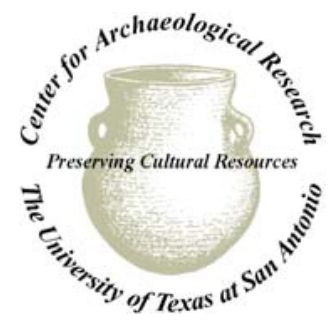

(C)2006

Archaeological Report, No. 368

Center for Archaeological Research

The University of Texas at San Antonio 


\title{
Archaeological Testing Associated with the Stabilization of Room 4 at Mission San Juan Capistrano, San Antonio, Bexar County, Texas
}

\author{
by \\ Jennifer L. Thompson \\ with contributions by \\ Barbara A. Meissner and Kristi M. Ulrich
}

Texas Antiquities Permit No. 4126

Principal Investigator

Steve A. Tomka

Prepared for

Ford, Powell, and Carson, Architects and Planners, Inc. 1138 East Commerce Street San Antonio, Texas 78205
Prepared by

Center for Archaeological Research The University of Texas at San Antonio Archaeological Report, No. 368 
A list of publications offered by the Center for Archaeological Research is available. Call (210) 458-4378; write to the Center for Archaeological Research, The University of Texas at San Antonio, One UTSA Circle, San Antonio, Texas 78249-1644; e-mail to car@utsa.edu; or visit CAR's web site at http:/car.utsa.edu. 


\begin{abstract}
In May 2006, The Center for Archaeological Research excavated one test unit at the exterior north wall of Room 4, west of the chimney at Mission San Juan Capistrano. The excavation occurred to assess the condition of the foundation and the dimensions of a more recent concrete footing before restoration of the collapsed north wall. The excavation found disturbed deposits throughout the test unit, but was able to locate and record the architectural features for Ford, Powell, and Carson, Architects and Planners, Inc., the project sponsors. A composite map of all excavations conducted at the mission since 1931 is included with descriptions of the agency, dimensions and location of all excavations as reported to aid future cultural resource management of Mission San Juan Capistrano.
\end{abstract}




\section{Table of Contents}

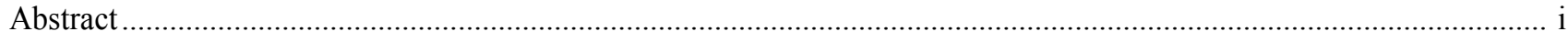

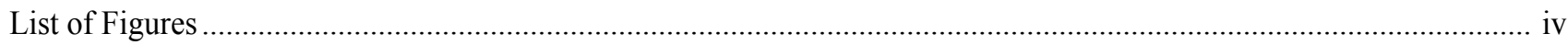

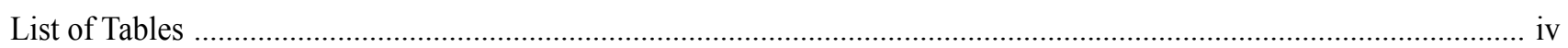

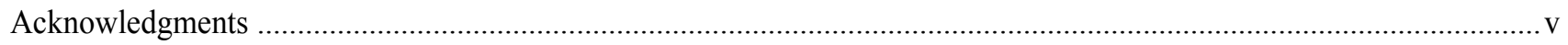

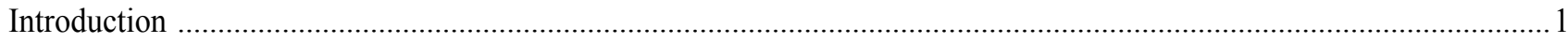

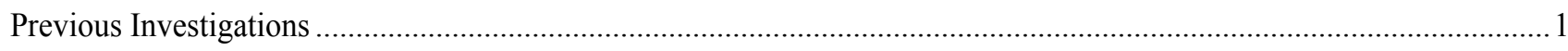

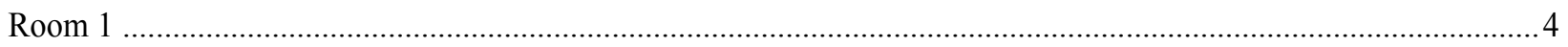

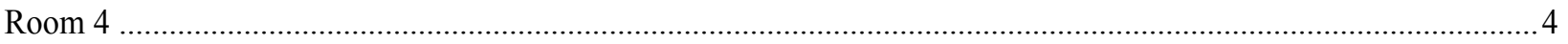

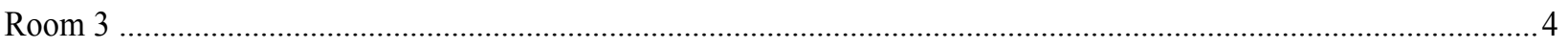

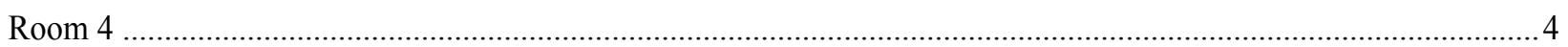

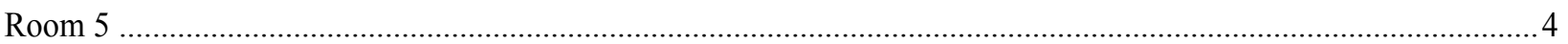

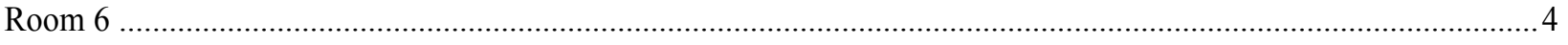

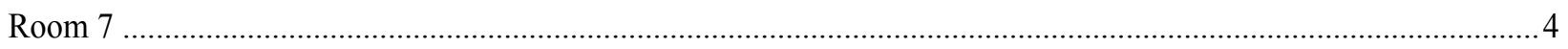

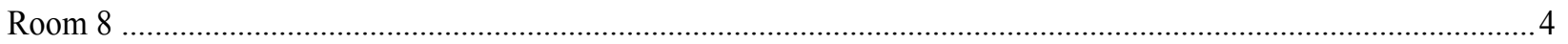

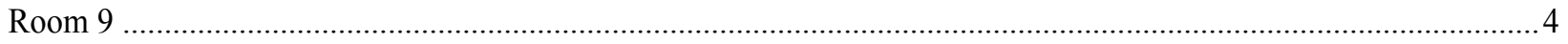

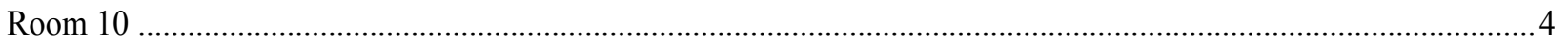

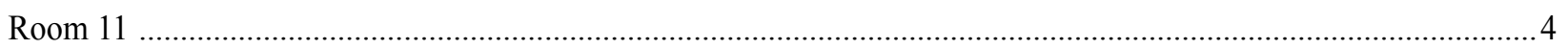

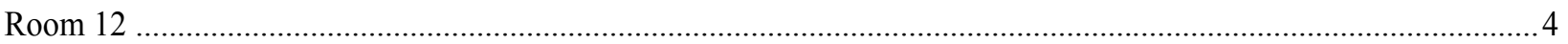

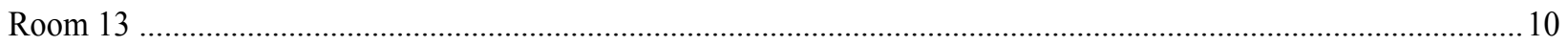

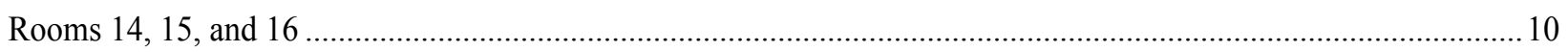

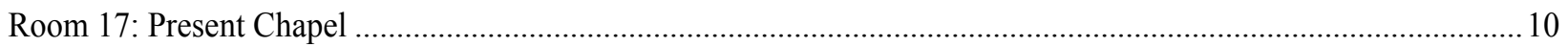

Room 18: Convento, 1930s Parish Hall, Modern Museum ................................................................................. 10

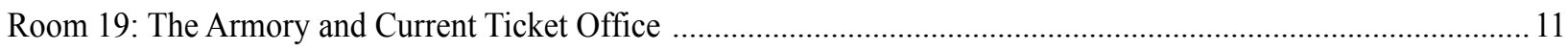

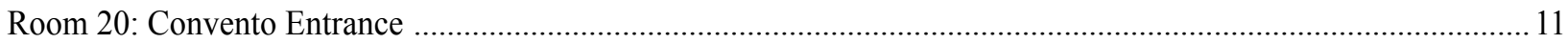

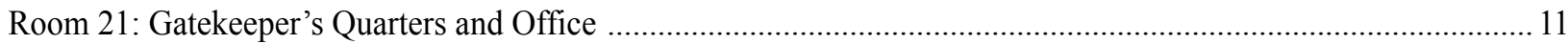

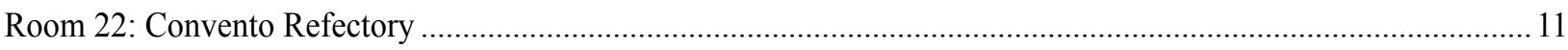

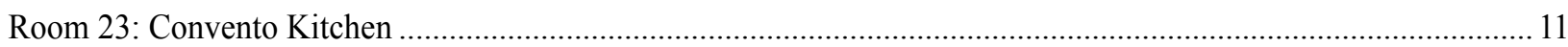

Rooms 24 and 25: Historic Small House, Modern Restrooms .............................................................................. 11

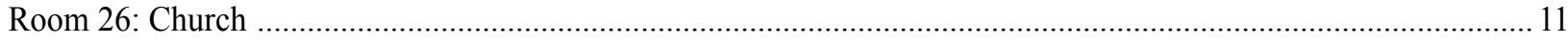

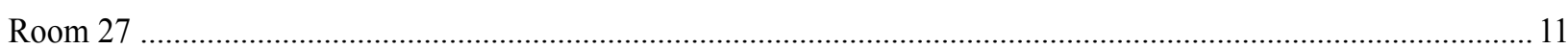

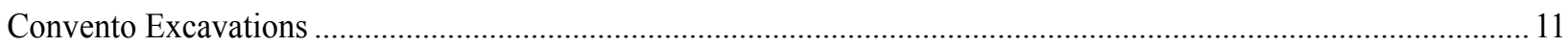

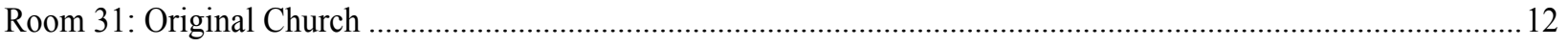

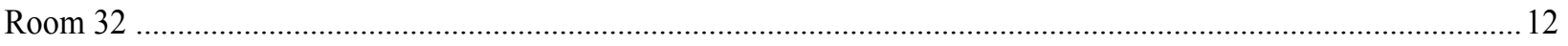

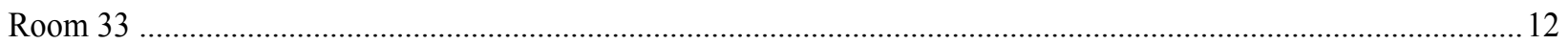




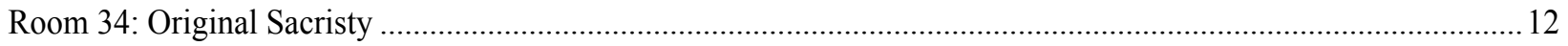

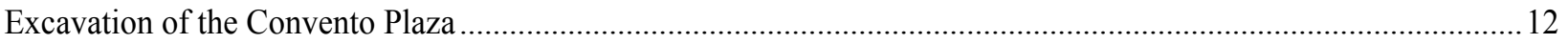

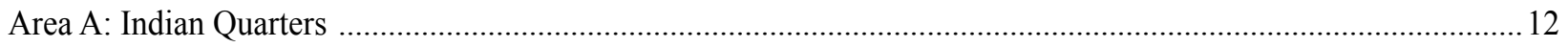

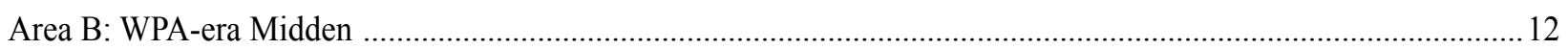

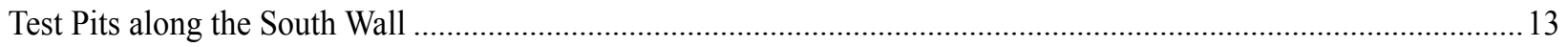

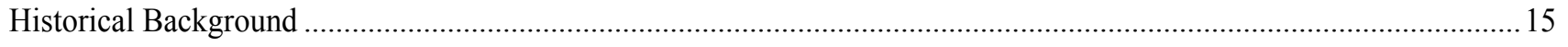

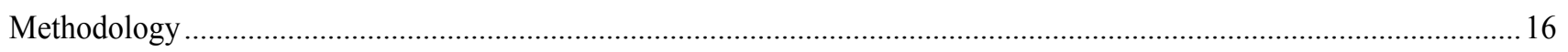

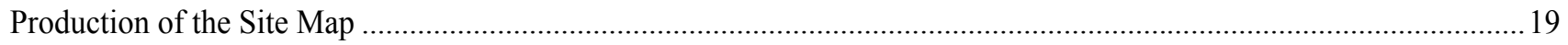

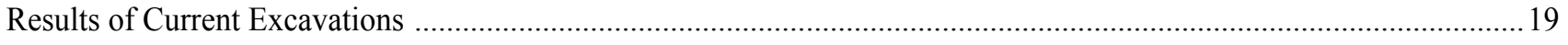

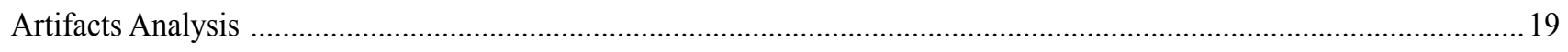

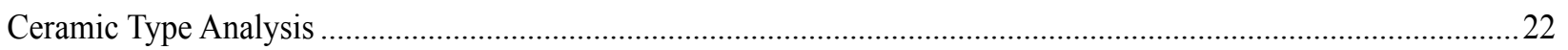

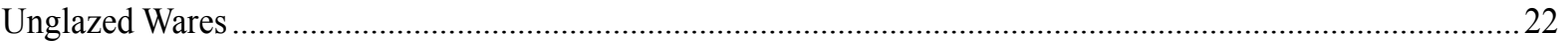

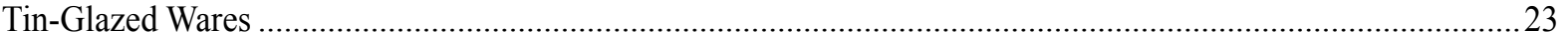

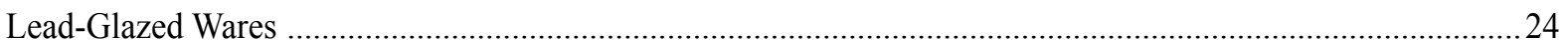

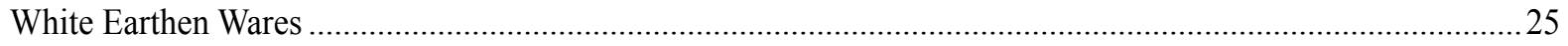

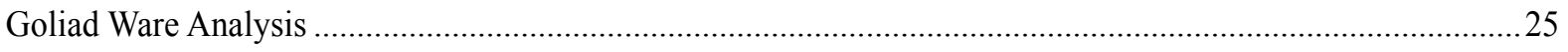

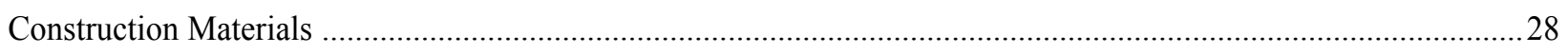

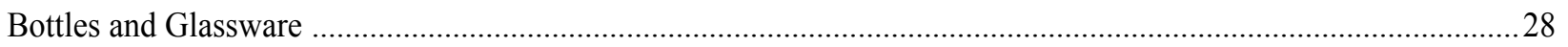

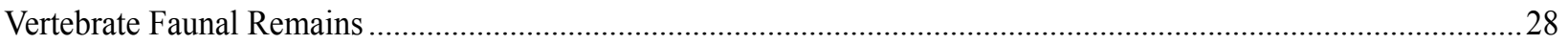

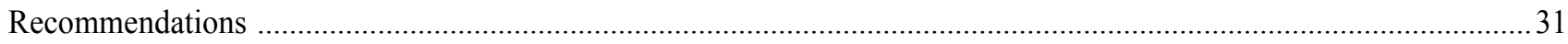

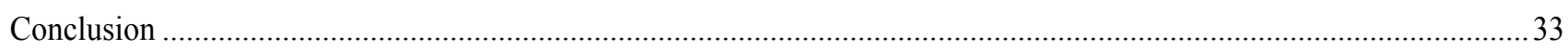

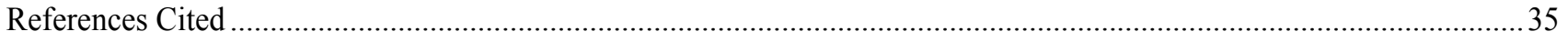

Appendix A: Summary of Previous Investigations at Mission San Juan Capistrano .................................................. A-1

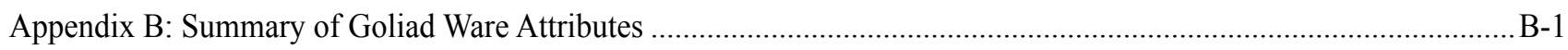




\section{List of Figures}

Figure 1. The location of Test Units 1 and 2 within Mission San Juan Capistrano. ..............................................................2

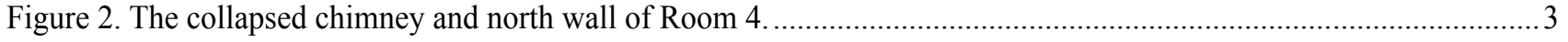

Figure 3. The composite map of all excavations reported at Mission San Juan Capistrano in or near the compound.

Date indicates year of excavation.

Figure 4. Composite map of all excavations reported beyond the compound walls at Mission San Juan Capistrano.

Date indicates year of excavation.

Figure 5. Redrawn versions of Smith's WPA footprint of the mission compound (based on Schuetz 1968:Figure 1). ........7

Figure 6. Schuetz's (1980:Figure 1:3) map of the 1971 excavations in the southern end of the compound. ......................8

Figure 7. Overlay of Schuetz's 1971 excavation map onto Smith's WPA footprint. .............................................................

Figure 8. Plan view drawing of Test Unit 1 at $70 \mathrm{cmbd}$, the bottom of the excavation. .................................................... 17

Figure 9. Photograph of final excavation of Test Unit 1. .................................................................................... 18

Figure 10. Photograph of the chimney footing exposed in Test Unit 1.......................................................................20

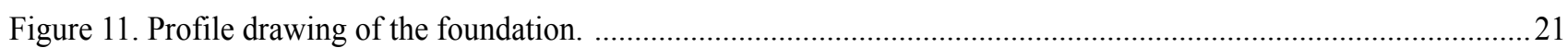

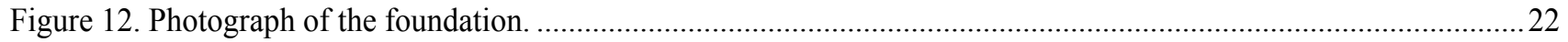

\section{List of Tables}

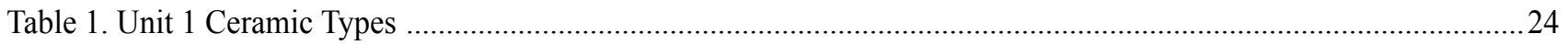

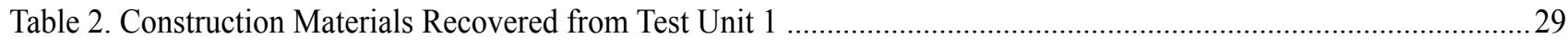

Table 3. Household Items and Toys Recovered from Test Unit 1 ...............................................................................29

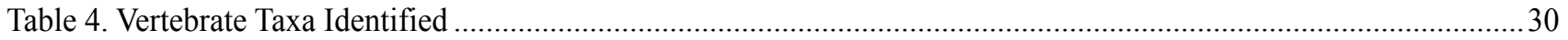

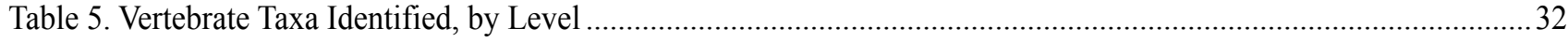

Table A-1. Summary of Previous Investigations at Mission San Juan Capistrano ........................................................ A-2

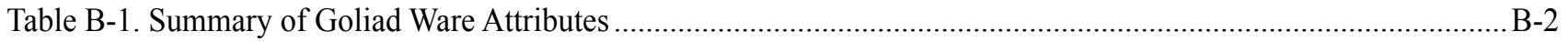




\section{Acknowledgments}

The authors would like to thank Susan Snow of the National Parks Service, the park staff at Mission San Juan Capistrano, and Carolyn Peterson of Ford, Powell, and Carson, Architects and Planners, Inc. for their cooperation with the Center for Archaeological Research during this archaeological excavation. Jennifer Thompson served as Project Archaeologist with assistance from Lindy Martinez during field excavations. Bruce Moses created the figures and the site map of previous excavations. Claudia Branton assisted with the graphics and served as report editor. 


\section{Introduction}

In May 2006, the Center for Archaeological Research (CAR) of The University of Texas at San Antonio (UTSA) conducted testing at one location along the north wall outside Room 4 at the northwest corner of the Mission San Juan Capistrano compound (41BX5) (Figure 1). This wall recently collapsed, so the architectural firm Ford, Powell, and Carson, Inc. contracted archeological services to expose the structure's foundation for examination of its integrity before restoring and reinforcing the wall (Figure 2). This report describes the results of those excavations and provides a lengthy summary of previous excavations and a composite map showing the location of all the reported excavations since the 1960s (Figures 3 and 4). We also report on the results of attribute analysis of the Goliad ware ceramics recovered from the test unit.

Mission San Juan Capistrano is a State Archeological Landmark (SAL) and listed on the National Register of Historic Places (NRHP). It is one of four Spanish colonial missions within the San Antonio Missions National Historic Park though city and federal agencies share control of the property. The Archdiocese of San Antonio controls all alterations to the physical plant, while the National Parks Service controls alteration to the grounds. The mission's SAL and NRHP status require professional archeological investigations prior to disturbing the grounds. The excavation of one test unit was conducted under Texas Antiquities Permit No. 4126. Steve A. Tomka served as Principle Investigator.

\section{Previous Investigations}

Several archaeological investigations have been conducted at Mission San Juan Capistrano since the Works Progress Administration (WPA) first reconstructed portions of the compound (Cargill and Robinson 2000; Córdova et al. 2005; Cox 1999; Cox et al. 2001; Escobedo 1980; Fox 1993, 1999; Fox and Cox 2000; Gross 1998; Schuetz 1968, 1969, 1974; Scurlock 1976; Turner 1988). Further research studies have been conducted on the artifacts recovered from these investigations (e.g., Carlson 1994; Cargill 1996; Cargill and Hard 1999; Francis 1999; Munoz 2004; Thoms 2001; Ulrich 2004 ). Mardith Schuetz conducted the most extensive work inside the compound in the late 1960s and early 1970s. Since then, several small projects have occurred in advance of proposed improvements to the park. CAR has taken the opportunity posed by the current project to construct a composite map of the previous archeological units (i.e., shovel tests, test units, backhoe trenches) excavated and to describe the extent of those excavations at Mission San Juan Capistrano as reported over the years. Included in these maps are the original WPA footprint (Figure 5) of the compound and Schuetz's 1971 excavation of the convento in the south end of the compound (Figure 6). Because these two important maps do not correspond well, as shown in Figure 7, we have used the WPA map on which to plot excavation locations. For a summary description of findings during some of these excavations, see Thoms 2001.

Harvey P. Smith, Sr. conducted the first excavations at San Juan for the Civil Works Administration and Texas Relief Commission in 1933 (Schuetz 1980), and in the late 1930s with financing by the WPA and the Archdiocese of San Antonio (Schuetz 1968). Smith found walls of the Indian quarters, the unfinished church on the east compound, and other buildings inside the quadrangle (Scurlock et al. 1976). Smith's footprint of the compound published in Schuetz 1968 (Figure 1) has served as the base map for all reported projects discussed here (Figure 5).

We found no other work reported until Mardith Schuetz of the Witte Museum began an extensive excavation project in January 1967 before the restoration of the WPA construction. She returned in 1968, 1969, and 1971 with particular interest in determining a building sequence and retrieving artifacts from the indigenous people who resided there (Schuetz 1968). The multi-year project completely excavated the interior of Rooms 4 through 13 and Rooms 19 through 22 (see Figure 3). They also included portions of the main plaza (Area A), a midden (Area B), church, and Rooms 1, 2, 17-18, 23, 27, 29, and 31-34 (Schuetz 1968, 1980).

In January 1967, complete excavations of Rooms 4 through 13 occurred. These were to be restored as houses for the priests and custodians of the mission. Partial excavation of Rooms 1, 2, 26, and 19 through 22 occurred. Areas in the north wall around Rooms 17, 18, 22, 27, 29, Area A, and Area B were excavated. The results of these excavations are reported in Schuetz 1968 and 1969. 


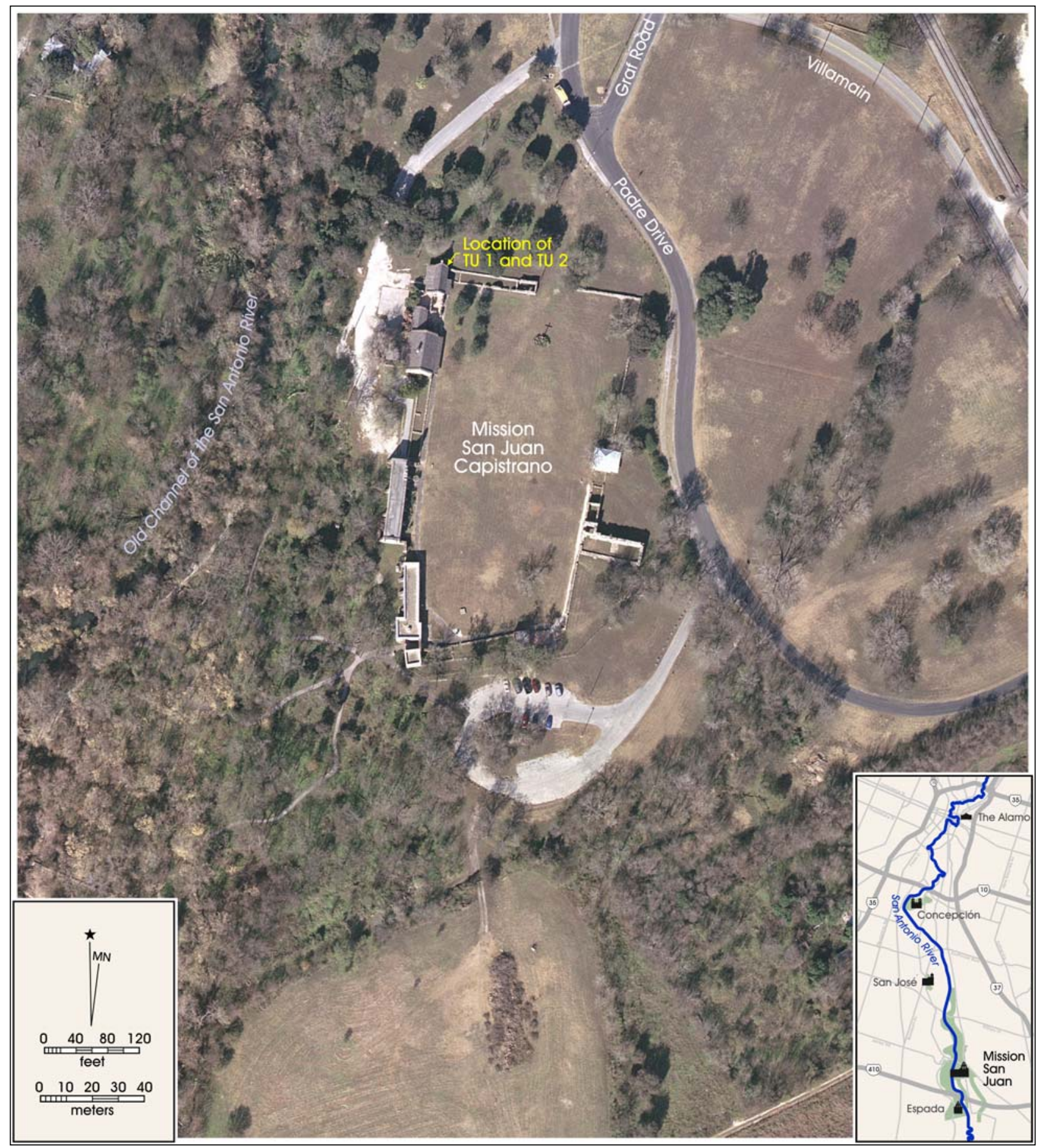

Figure 1. The location of Test Units 1 and 2 within Mission San Juan Capistrano. 


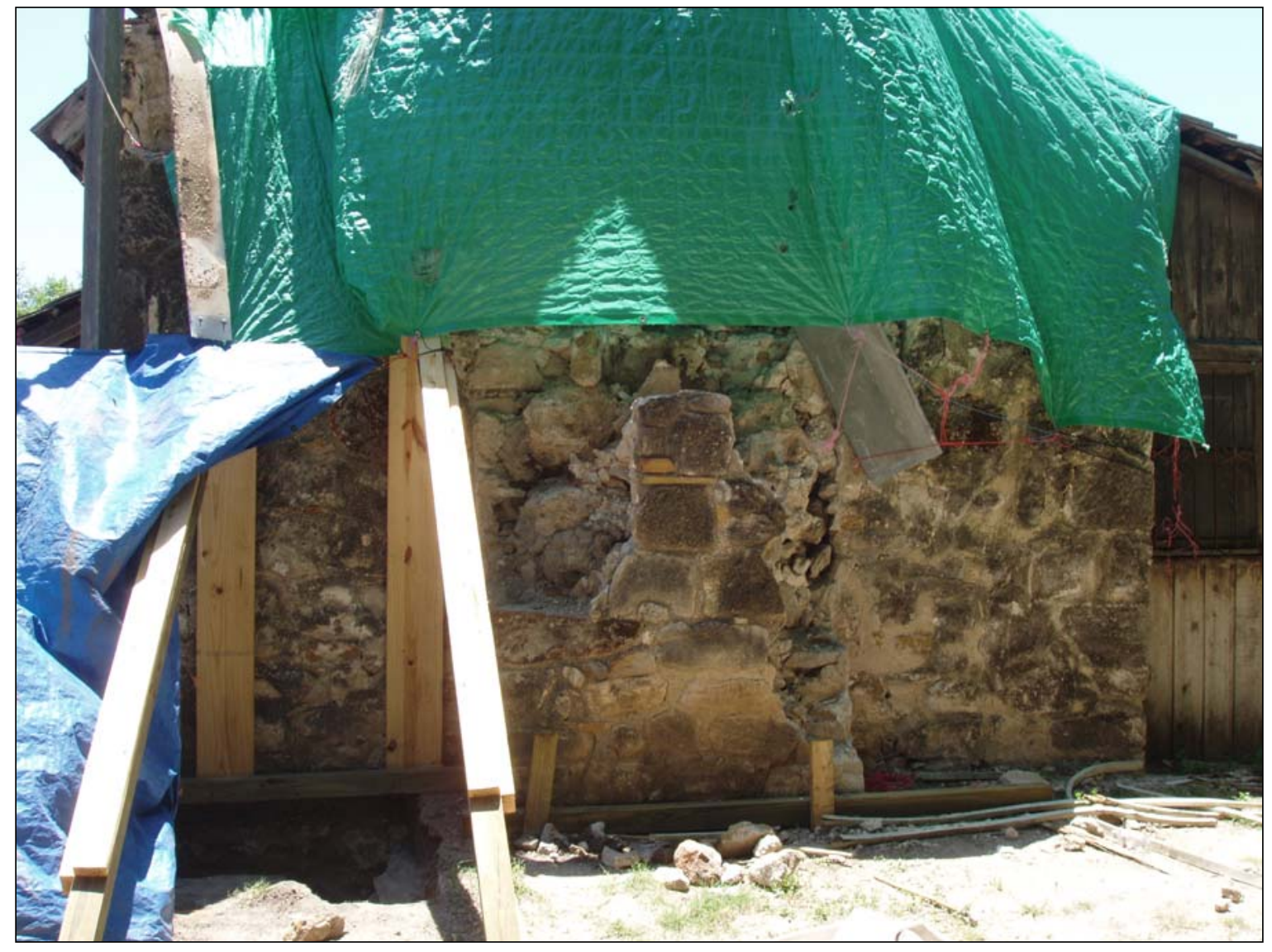

Figure 2. The collapsed chimney and north wall of Room 4. 
The 1968 excavations occurred prior to renovations to the chapel and the southwest corner of the compound. Excavations at this time included Level 3 of the midden in Area B, excavation of the colonial floor in Room 19, re-excavation of Room 21 and portions of Room 20, test pit excavation around the southern walls of the compound, screening of the midden material removed from Room 18, and test pit excavation in front of the pilasters of the chapel (Room 17) (Schuetz 1980:4-5).

Work during the fall of 1969 included the excavation of the chapel (Room 17) before its restoration (Schuetz 1974).

The 1971 work sought to excavate entirely the buried portion of the convento located in the southwest corner of the compound (Schuetz 1980:5).This included the excavation of Rooms 22, 23, 31, 32, 33 and 34 and Units 4, $5,6,7,8,9,13,14,15,16,17,18,23,24,25,42$, and 43 (Schuetz 1980). A copy of Schuetz's excavation map is included as Figure 6.

The following paragraphs describe Schuetz's excavation by room rather than chronology to provide a quick reference for those interested in the scope of excavation in these rooms, not the findings, which are outlined in Schuetz 1968, 1969, 1974, and 1980. These descriptions along with a composite map and table of excavation locations should aid future planning of excavation and prevent redundant work at the mission (Figures 3 and 4; Appendix A:Table A-1). Schuetz uses the term unit in the manuscript of the 1971 excavation; however, the artifact bags, maps, and all curated materials from that season were labeled with the term square (Schuetz 1980). The terms are interchangeable for that season.

\section{Room 1}

The room was unexcavated except for a pit in the southeast corner, which revealed the south and east wall bases at $1.4 \mathrm{ft}$. below surface (ftbs).

\section{Room 4}

One test pit was dug against the north wall to find the cross-walls of Rooms 2 and 3. One pit measured 5-x-2 ft. It reached $3 \mathrm{ftbs}$ and revealed a fire pit.

\section{Room 3}

One test pit uncovered the old wall and reached $3.6 \mathrm{ftbs}$.

\section{Room 4}

All of Room 4 was excavated in five levels to $3.5 \mathrm{ftbs}$.

\section{Room 5}

All of Room 5 was excavated in three levels.

\section{Room 6}

All of Room 6 was excavated in four levels.

\section{Room 7}

All of Room 7 was excavated in five levels.

\section{Room 8}

All of Room 8 was excavated in four levels.

\section{Room 9}

All of Room 9 was excavated in five levels.

\section{Room 10}

All of Room 10 was excavated in five levels.

\section{Room 11}

All of Room 11 was excavated in two levels, only to the base of the walls at $1.0 \mathrm{ftbs}$ except in the northwest corner and along the south wall.

\section{Room 12}

All of Room 12 was excavated in two levels. 


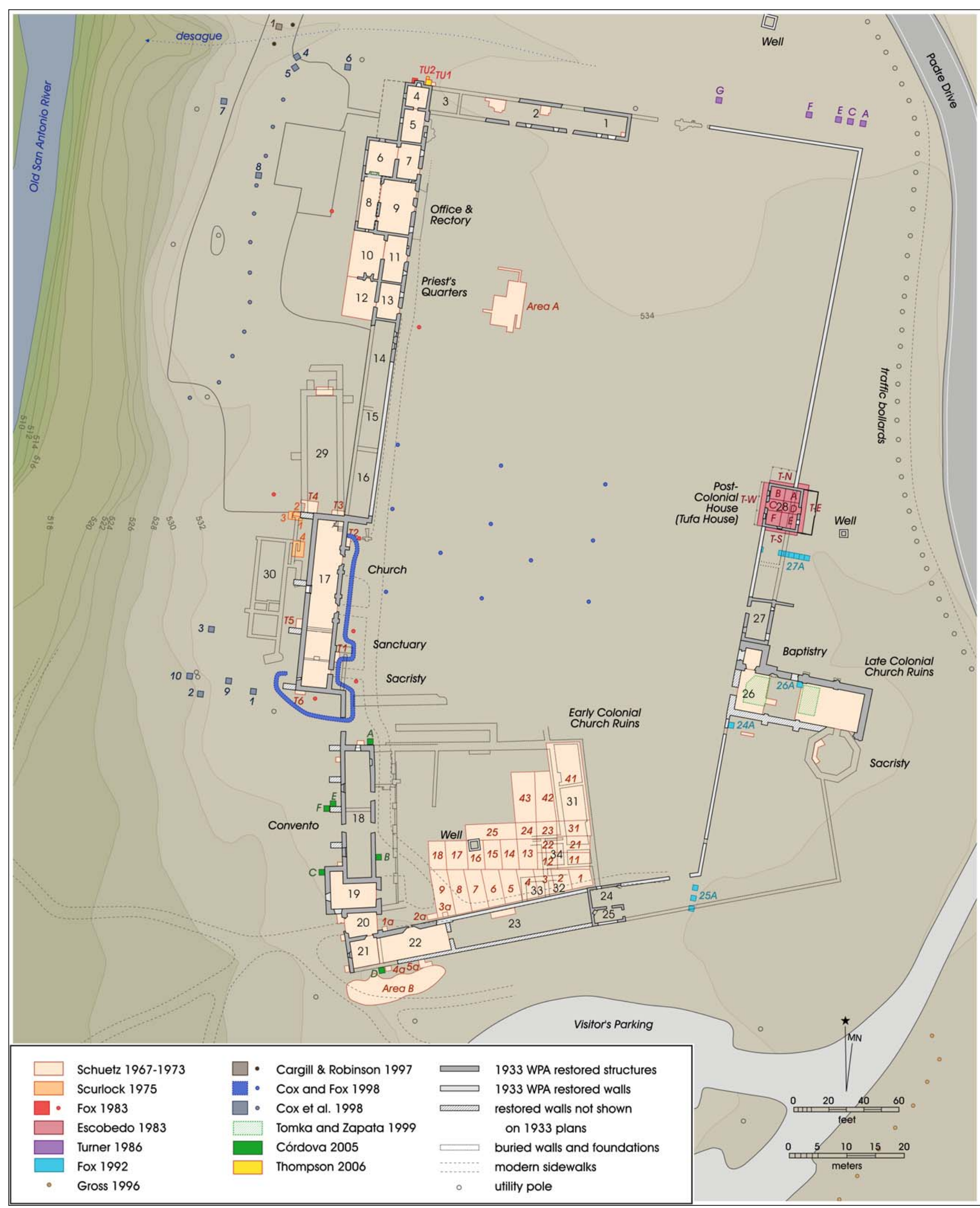

Figure 3. The composite map of all excavations reported at Mission San Juan Capistrano in or near the compound. Date indicates year of excavation. 


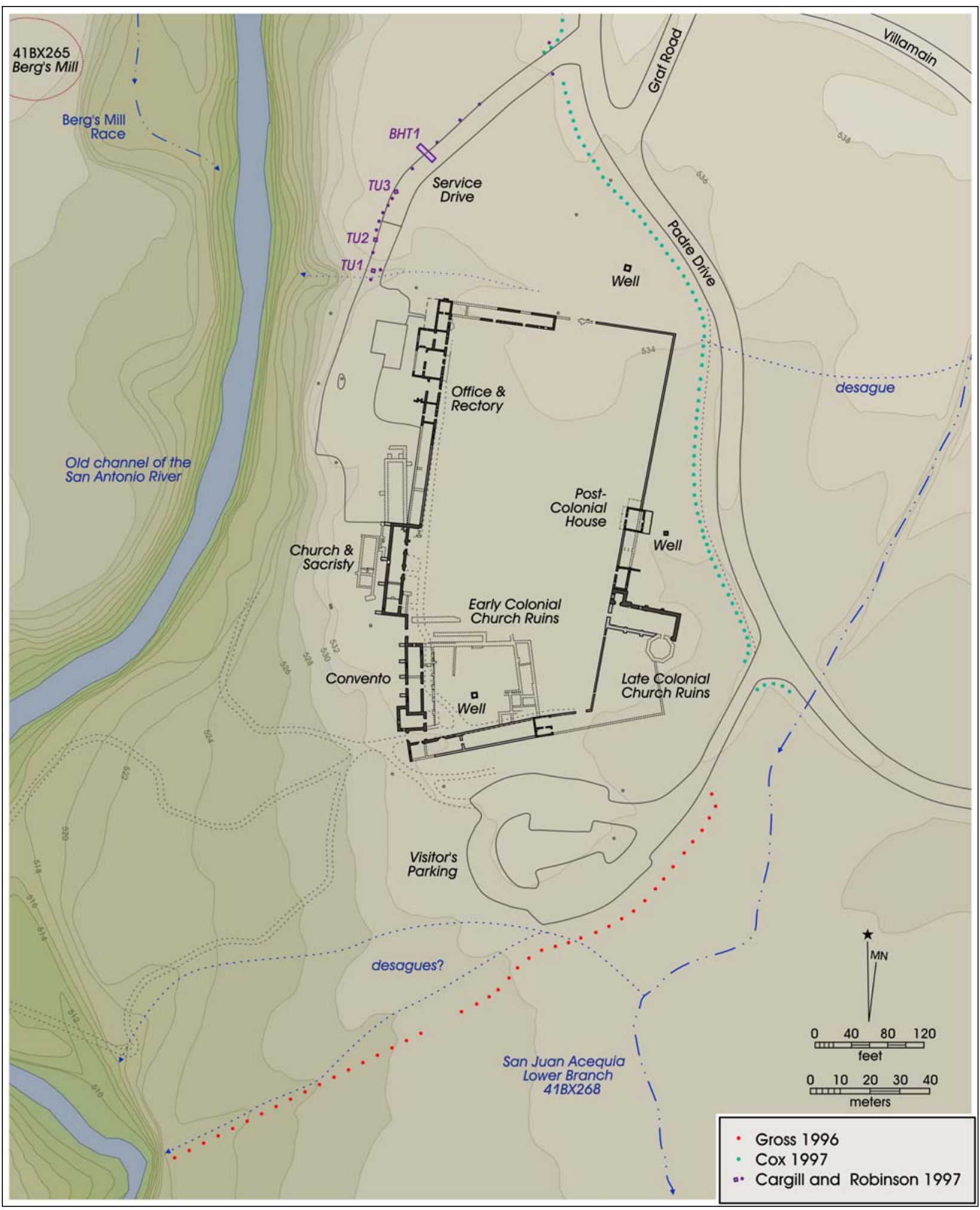

Figure 4. Composite map of all excavations reported beyond the compound walls at Mission San Juan Capistrano. Date indicates year of excavation. 


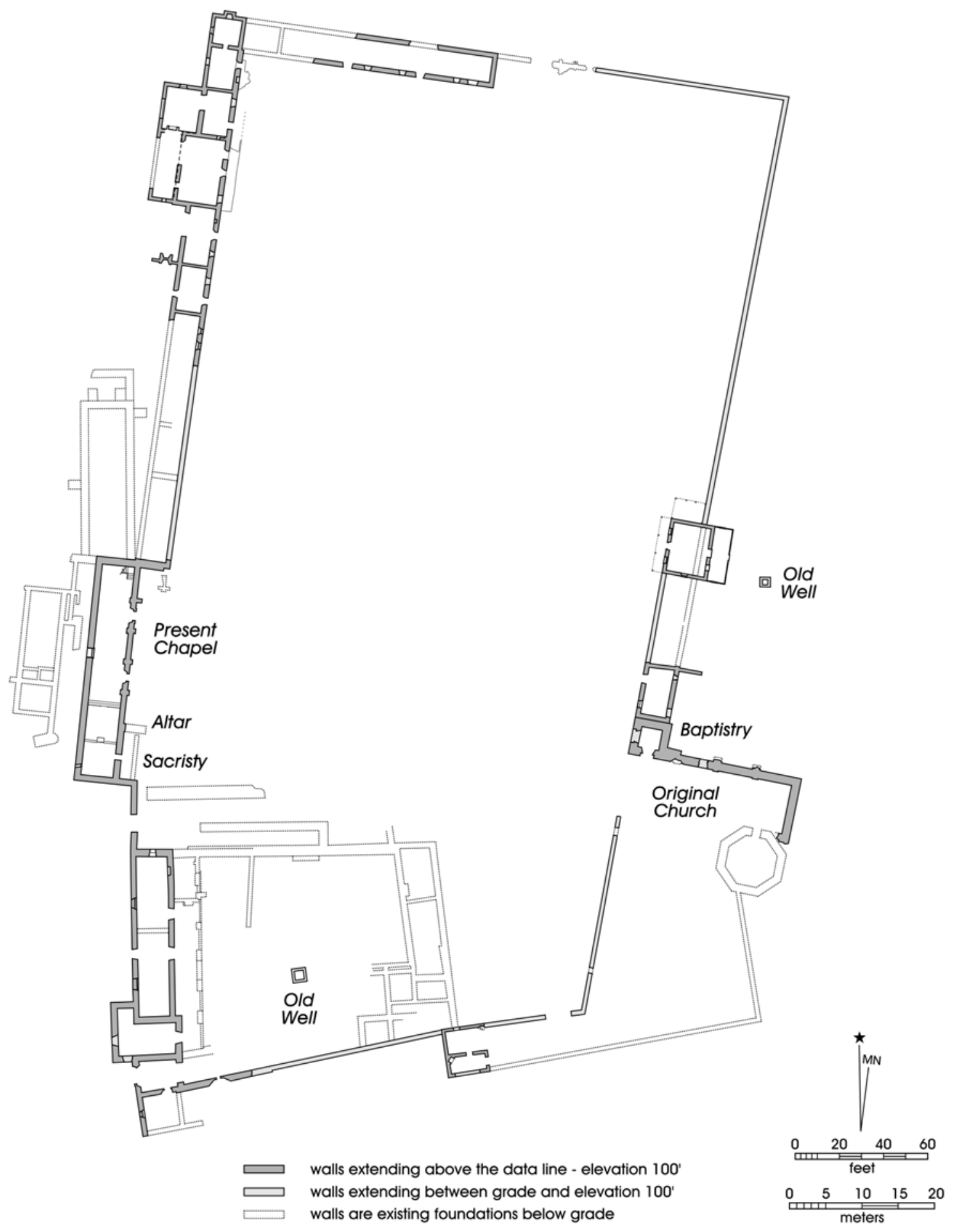

Figure 5. Redrawn versions of Smith's WPA footprint of the mission compound (based on Schuetz 1968:Figure 1). 


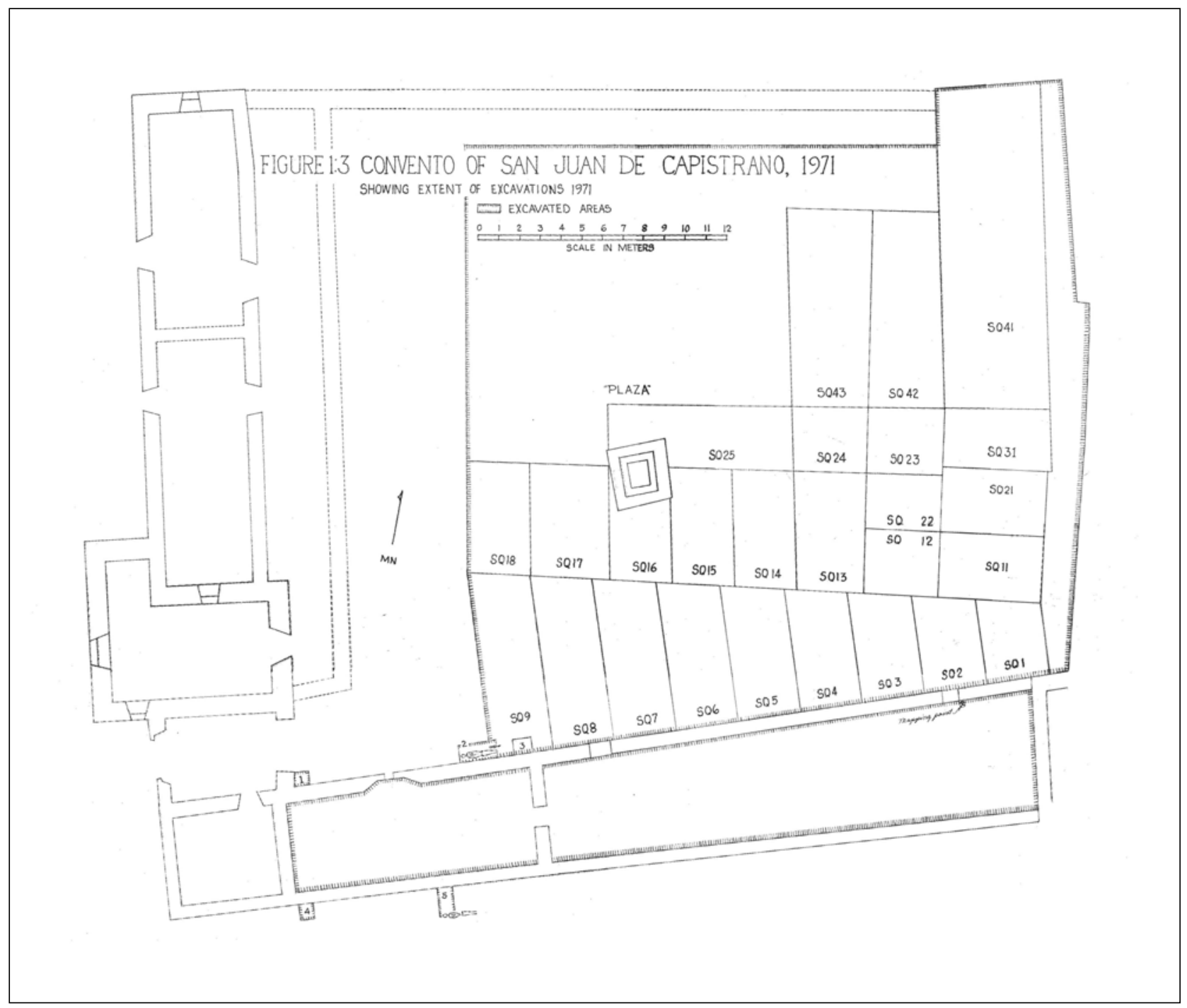

Figure 6. Schuetz's (1980:Figure 1:3) map of the 1971 excavations in the southern end of the compound. 


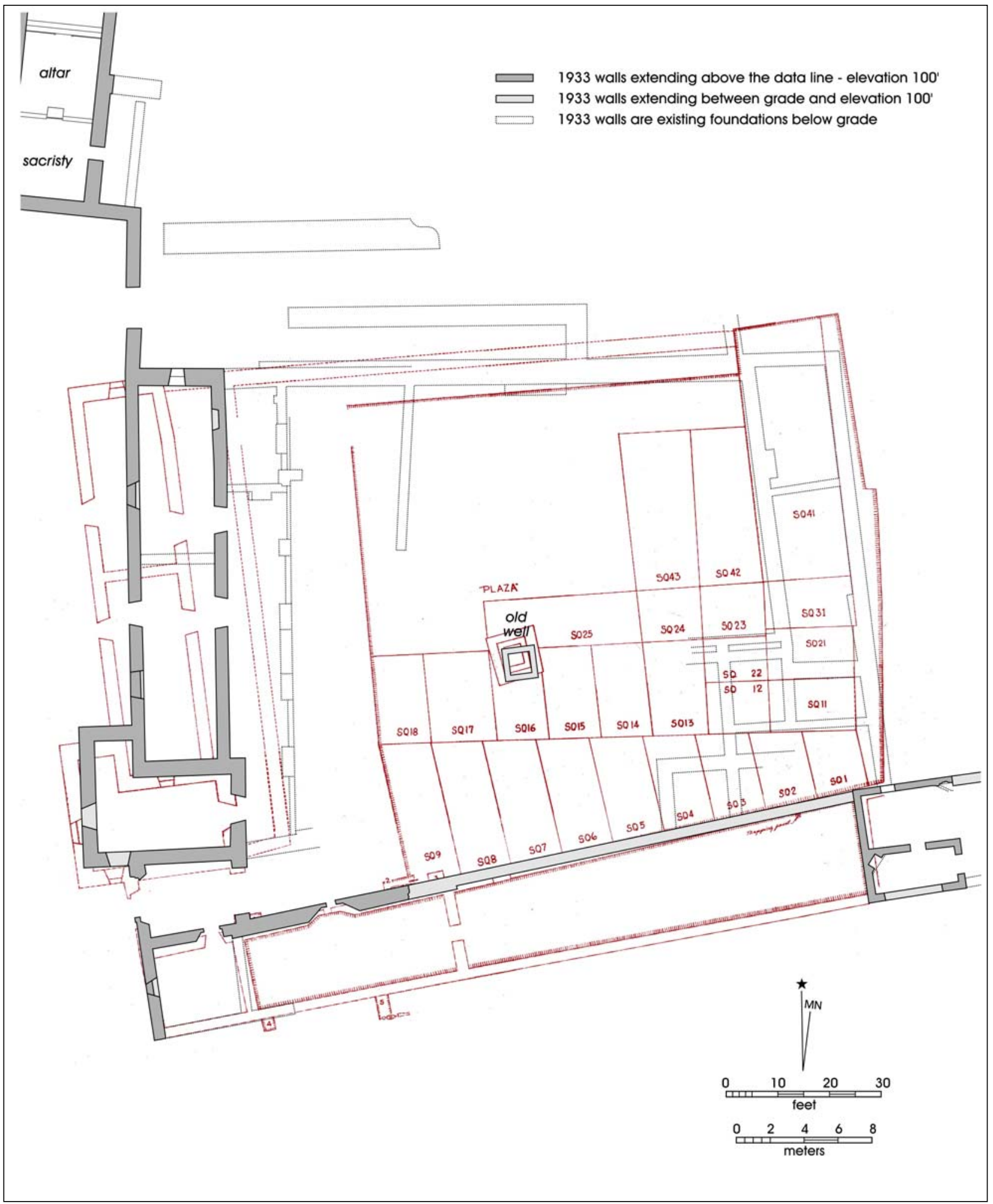

Figure 7. Overlay of Schuetz's 1971 excavation map onto Smith's WPA footprint. 


\section{Room 13}

All of Room 13 was excavated in three levels.

\section{Rooms 14, 15, and 16}

No excavation was reported in these rooms.

\section{Room 17: Present Chapel}

In 1967, six test trenches were excavated around the exterior of Room 17, the present chapel and its sacristy (Schuetz 1968). Trench 1 was dug between the sacristy door and the buried foundation. It measured $6.2-\mathrm{x}-2.0 \mathrm{ft}$. The bottom of the wall was discovered $4.0 \mathrm{ftbs}$. A stone footing $0.3 \mathrm{ft}$. wider than the footing reinforces the wall here. The footing was recorded $1.0 \mathrm{ftbs}$ and $3.0 \mathrm{ft}$. deep.

Trench 2 was dug next to a buttress on the north side of the northern chapel door. It measured 5.2-x-2.4 ft. No support was recorded for the wall here. The bottom of the wall was recorded $2.8 \mathrm{ftbs}$ while the base of the buttress was $3.5 \mathrm{ftbs}$ at the time of excavation.

Trench 3 was excavated outside the northeast corner of the room. It measured $6.9-\mathrm{x}-1.9 \mathrm{ft}$. The trench revealed that the base of the wall was $3.7 \mathrm{ft}$. below ground with no footing. The west wall of Room 16 and the east wall of Room 29 were uncovered in this trench.

Trench 4 was excavated $6.4 \mathrm{ft}$. north and $5.5 \mathrm{ft}$. west at the interior, southwest corner of Room 29 (the northwest, exterior of Room 17). It exposed the stone footing supporting the corner of the church. The footing measured $2.1 \mathrm{ft}$. wide.

Trench 5 was placed $15.6 \mathrm{ft}$. south of the large west wall window and measured $6.4-\mathrm{x}-2.75 \mathrm{ft}$. The wall foundation exposed in this trench measured $4.2 \mathrm{ftbs}$.

Trench 6 was placed in the southwest corner outside the sacristy and measured 5.6-x-1.8 ft. Here the base of the wall was uncovered at $3.85 \mathrm{ftbs}$.

In 1968, five test units were excavated before each pilaster of the chapel façade to obtain foundation data (Schuetz 1980:13-17). The units are described from north to south.
Test Unit 1 lay just north of the northernmost door. The pilaster footing was found at $2.8 \mathrm{ftbs}$.

Test Unit 2 lay just south of the northernmost door. This pilaster rested on a stone $1.7 \mathrm{ftbs}$. Sterile soil lay $1.8 \mathrm{ftbs}$.

Test Unit 3 lay just north of the middle door. The pilaster rests on a footing $1.9 \mathrm{ftbs}$.

Test Unit 4 lay just south of the middle door. The bottom of the footing is $4.1 \mathrm{ftbs}$. A trench was dug from this wall by machine.

Test Unit 5 was placed at the south end of the nave. The bottom of the pilaster was $4.5 \mathrm{ftbs}$.

Returning in 1969, Schuetz excavated in Room 17 and identified six floor surfaces and two building phases. She also excavated 92 individuals (Schuetz 1974).

\section{Room 18: Convento, 1930s Parish Hall, Modern Museum}

In 1967, three test pits were excavated around Room 18, the original monastic quarters later used as a parish hall (Schuetz 1968).

Test Pit 1 was placed $6.0 \mathrm{ft}$. from the northeast corner of the room and measured 3.6-x-2.5 ft. Excavation stopped at $2.0 \mathrm{ftbs}$ uncovered a large rock thought to support the foundation.

Test Pit 2 was dug against the west wall, $13.0 \mathrm{ft}$. from the northwest wall and measured $2.5-\mathrm{x}-3.1 \mathrm{ft}$. The bottom of the wall was exposed in this unit at $4.5 \mathrm{ftbs}$.

Test Pit 3 was dug at the juncture of the north wall of Room 19 and the west wall of Room 18. The unit was 2.6-x-2.6 ft. This unit exposed a footing from 2.9 to $3.45 \mathrm{ftbs}$.

In 1968, renovation to Room 18 occurred after vandalism and deterioration caused portions of the structure to collapse. The collapse revealed new information on the construction of the room. Work in 1968 was limited to re-measuring the room's dimensions and screening dirt excavated from holes along the east wall of the room. Concrete footings were poured into these holes to support the buttresses at the back wall (Schuetz 1980:13). 


\section{Room 19: The Armory and Current Ticket Office}

In 1967, all of Room 19 was excavated in four levels, revealing three floors. Excavations reached at least $2.1 \mathrm{ftbs}$. Along the north wall, excavation reached $7.6 \mathrm{ftbs}$. These 1967 excavations stopped in Level 4, between Floor 2 (1.8 ftbs) and Floor 3 (2.1 ftbs) (Schuetz 1968:157-170; 1980). The room was re-excavated in 1968 prior to restoration. At this time, three adult skeletons were excavated in the western end of the room, thought to be a closet (Schuetz 1980:8).

\section{Room 20: Convento Entrance}

All of Room 20 was excavated in three levels in 1967 and then backfilled with screened dirt. In 1968, Schuetz re-excavated the corners of Room 20 to establish original floor levels for renovation (Schuetz 1980).

In 1967, two test pits were excavated along the west wall of Room 20, one dug on each side of the exterior door. Test Pit 1 was placed on the north side of the door, extending $5.2 \mathrm{ft}$. from the corner of Rooms 19 and 20 to just past the gate's edge. The unit was $2.5 \mathrm{ft}$. wide. Here the foundation was exposed at $2.9 \mathrm{ftbs}$. Excavations ended $4.3 \mathrm{ftbs}$. Test Pit 2 was excavated south of the gate $1.2 \mathrm{ft}$. from the edge of the door, 3.2-x-2.0 ft. The foundation exposed in this unit showed a crumbling wall varying from 1.0 to $2.4 \mathrm{ftbs}$. Excavation stopped in this unit $3.0 \mathrm{ftbs}$ (Schuetz 1968:170-176).

\section{Room 21: Gatekeeper's Quarters and Office}

In 1967, the entire interior of the room was excavated to $1.5 \mathrm{ft}$. below ground. Test Pit 1 was excavated at the exterior, southwest corner and measured 3.0-x-2.4 ft. The wall base was uncovered at $1.0 \mathrm{ftbs}$ resting on a footing that extended $1.3 \mathrm{ftbs}$ (Schuetz 1968:176-183). After 1967 excavations, the entire room was backfilled with screened dirt. In 1968, the entire colonial floor in Level 3 was re-excavated to establish the original floor levels prior to restoration (Schuetz 1980:10-11).

\section{Room 22: Convento Refectory}

In 1967, the entire interior of the room was excavated in two, six-inch levels. Level 3 was started along the northern wall. Excavation stopped before foundation information was recorded. Trenching also occurred in this room $30 \mathrm{ft}$. from the west wall and $5.5 \mathrm{ft}$. west of the east wall built by the WPA (Schuetz 1980:21). In 1971, excavation continued during a pause in the convento excavations. During this time, new dimensions of the room were measured and two floors recorded (Schuetz 1980:23).

\section{Room 23: Convento Kitchen}

In 1967, one test pit measuring 14.0-x-3.5 ft. was excavated to $2.1 \mathrm{ftbs}$ in this room. In 1971, the room was excavated in levels: Level 1 above the nineteenth century floor (0-1.0 ftbs), Level 2 (1.0-1.6 ftbs) from the nineteenth to the eighteenth century floor (Schuetz 1968). During the 1971 excavation, two pit features were recorded, including an adult skeleton (Schuetz 1980).

\section{Rooms 24 and 25: Historic Small House, Modern Restrooms}

No excavation occurred in these rooms.

\section{Room 26: Church}

This was excavated during the 1967 field season. The primary purpose of the excavation in the old church was to recover burials. There, workers only screened burial fill. Excavation began at the back $10.5 \mathrm{ft}$. of the church and the baptistery, which was excavated as a single unit. Eighteen human burials were found. Schuetz's excavation maps show other excavation not found in the text (Schuetz 1968). These include an area $16 \mathrm{ft}$. west of the west wall and $36 \mathrm{ft}$. east of the east wall. The map also indicates part of the sacristy was excavated, specific provenience is not noted.

\section{Room 27}

A 2.0-ft. wide trench along the north wall of the room is the only excavation conducted here in 1967.

\section{Convento Excavations}

The 1971 excavations of the convento began by setting up a grid and locating walls. Excavation proceeded within units that conformed to walls and were not square. Rooms were assigned numbers in the order in which they were found. 
Excavation began in the east and progressed to the west. The first units were excavated in two levels. Level 1 was one foot. Level 2 was just less than one foot to the colonial floor. Units 1 through 4, Room 22 and Room 23 contained nineteenth century living surfaces. After the nineteenth century surface was removed, excavation by levels stopped in all areas. In Units 1 and 2, Level 1 measured from 8.5-10.0 in., the nineteenth century surface. Level 2 included 1.0-1.6 ftbs, beneath the nineteenth century floor to the colonial floor. Units 4 and 5, outside Room 33 were excavated to the colonial floor at $1.85 \mathrm{ftbs}$. Portions of Unit 4 within Room 33 are described under Room 33 below.

Most excavation was done by hand and screened, though the northwest portion of the convento was mechanically excavated after all rooms and the patio was cleared (Schuetz 1980:18). One-half foot was mechanically stripped from the patio as well. Not all matrixes from the mechanically scraped areas were screened.

Several building phases were discerned in the southeastern corner of the convento. Most complicated is the sequence of the eastern half of Room 23 and Rooms 32-33. This area includes Units 1-4. Determining the depth of excavation in these areas is difficult to discern from the excavation manuscript.

\section{Room 31: Original Church}

In 1971, Unit 11, eastern Unit 12, 21, 31, and 41 were excavated in Room 31 . Units 12 and 21 were excavated in levels. Level 1 was $0-1.0 \mathrm{ftbs}$. Level 2 (1.0-1.83 ftbs) included the $10 \mathrm{in}$. between the colonial floor and Level 1. Units 31 and 41 were excavated directly to the colonial floor; others were not (Schuetz 1980:35). The WPA excavated a trench in this room along the interior walls, except at the northwest corner. Schuetz re-excavated another WPA trench in the west wall. Total depth here was $4 \mathrm{ft}$. below the colonial floor. Schuetz determined the foundation walls were $2.62 \mathrm{ft}$. below the colonial floor on a 10-in. mortar footing (Schuetz 1980:37).

\section{Room 32}

Unit 3 in this room was excavated in Levels 1 and 2 (1.0-1.1 ftbs). The colonial floor was uncovered at $1.1 \mathrm{ftbs}$.

\section{Room 33}

Unit 4 was excavated in levels in this room: Level 1 from 0-1.0 ftbs, Level 2 from 1.0-1.85 ftbs. Artifacts from Unit 4, which span from inside to outside the room, are designated Unit/Square 4-2 when referring to interior excavations.

\section{Room 34: Original Sacristy}

This room included excavation of Unit 22 and the western half of Unit 12. These were excavated in two levels in 1971: Level 1 from 0-1.0 ftbs, Level 2 from 1.0-1.1 ftbs, the colonial floor depth.

\section{Excavation of the Convento Plaza}

Units 5, 6, 7, 8, 9, 13, 14, 15, 16, 17, 18, 23, 24, 25, 42, and 43 were dug by hand from the surface directly to an ash layer on the colonial plaza floor $2.3 \mathrm{ftbs}$. All fill from these units was screened. Barbeque pits in Units 4, 5, 6, 8, 9, and 13 were filled with contemporary garbage. The pits in Units 5 and 6 were excavated to $4 \mathrm{ftbs}$. Pits in Units 4 and 13 were dug to $3.1 \mathrm{ftbs}$. Pits in Units 8 and 9 were dug to 3.11 $\mathrm{ftbs}$. The rest of the plaza not excavated within the units was mechanically scraped and not screened.

\section{Area A: Indian Quarters}

Area A was excavated to find the jacales, or Indian quarters used until ca. 1762. In 1967, two trenches were dug west to east, $25 \mathrm{ft}$. apart. The southern trench revealed a layer of stone $1.5 \mathrm{ftbs}$. The trench was extended to the northeast and south to find the limits of the stone feature. Exploratory trenches were placed $36 \mathrm{ft}$. north and south.

\section{Area B: WPA-era Midden}

A midden outside the south wall, across from Rooms 21 and 22 were designated Area B. This midden measured 50 $\mathrm{ft}$. and stood $4 \mathrm{ft}$. high above ground surface. The upper 2 $\mathrm{ft}$. (Levels 1 and 2) were excavated across the entire midden in 1967. An additional foot (Level 3: 2-3 ft. from the top of the midden) was excavated only in the western half, also in 1967. Materials from the midden were from the WPA's construction in the 1930s and contained a mixed component 
(Schuetz 1968, 1980). The eastern half of Level 3 was excavated in 1968 with a front-end loader and screened. Level 4 did not contain artifacts and was not screened (Schuetz 1980).

\section{Test Pits along the South Wall}

In 1968, a series of test units were excavated along the southern wall of the compound to retrieve construction data for restoration. They were specifically looking at the foundations for "the extent and quality of the WPA restoration" (Schuetz 1980:12). Excavation occurred with front-end loaders.

Unit 1a was dug at the corner of the Roman arch and the south wall. No footing was found for the south wall, which extended $4.35 \mathrm{ftbs}$. The wall with the arch reached $1.5 \mathrm{ftbs}$.

Unit 2a was located $26.9 \mathrm{ft}$. east of the same arch-corner along the north wall of Room 22. The front-end loader uncovered an adult burial $4.5 \mathrm{ftbs}$, one foot from the north wall and $10.7 \mathrm{ft}$. east of the eastern edge of the doorway to Room 22. An infant burial was found $2.8 \mathrm{ft}$. east of the adult burial, $3.5 \mathrm{ftbs}$.

Unit 3a was placed $39.7 \mathrm{ft}$. east of the arch-corner along the north wall to locate the beginning of the WPA excavation and uncover the foundation.

Unit 4a was excavated $20.6 \mathrm{ft}$. east of the southwest corner of Room 21. It reached $4.2 \mathrm{ftbs}$.

Unit $5 \mathrm{a}$ was placed $42.5 \mathrm{ft}$. from the southwest corner of Room 21. A third burial was uncovered here $4.2 \mathrm{ftbs}$.

Soon after Schuetz concluded her long excavation project, the City of San Antonio conducted an archaeological and historical survey from July to December 1974 over an area proposed to become the Mission Parkway of San Antonio. The goals of the survey were to document the history of the area, present an overview of the resources there, and recommend further research and preservation tactics. They recorded 84 sites, three relating to Mission San Juan Capistrano. These three were the San Juan Dam site, the San Juan Acequia, and a drainage ditch north of the mission complex (Scurlock et al. 1976).
Also in 1974, a trash midden was discovered during excavation of the drainage ditch to the north of the compound. Scurlock describes the contents of the midden as disturbed and therefore, undateable, though he conjectures the midden contains trash from all periods of the mission's use (Ulrich 2004; Scurlock et al. 1976).

Scurlock returned in 1975 with the Office of the State Archeologists to conduct excavations around the 1750s church (Room 17). Miguel Celorio, a University of Texas professor of architecture, examined the architectural form of the church. The goals of this project were in part to determine whether the structure was originally constructed as an "open chapel" form. Such an architectural form might have been more conducive to Native attendance of church services than a closed form (Scurlock 1976). Regardless of the reason, Scurlock and Celorio did confirm an open chapel form.

In order to determine the temporal relationship between the subsurface walls shown on Smith's 1934 plan of the mission and the open chapel form, Scurlock excavated test units around the church. Four test units were excavated on the west side of the church, three were located adjacent to a buttress at the northwest corner of the church, and the fourth was located $4.2 \mathrm{~m}$ south of this buttress and one meter west of the wall of the church (Figure 3). They exposed walls constructed of sandstone and limestone cemented with lime mortar and recovered Spanish Colonial, nineteenth century, Anglo, and twentieth century artifacts mixed in mottled soil, likely WPA backfill. They did not report the temporal relationship between the open chapel form and the construction of walls.

Test Units 1 through 3 were excavated in $15-\mathrm{cm}$ levels to $30 \mathrm{~cm}$ below surface (cmbs). Test Unit 4 went to $45 \mathrm{cmbs}$. The northeast portion of Test Unit 4 was excavated to $90 \mathrm{cmbs}$ and called Test Pit 4B. Cement plaster was also removed to expose the type of fill and techniques employed in order to deduce the whether the structure was an open chapel in its early years.

Foundation and construction were also the focus of James Ivey's work in 1982. He re-examined the construction methods, foundation depths, wall thickness, and alignments throughout the complex in order to establish a better understanding of the construction phases of the mission. His work included excavation along the south wall (Ivey 1982). No location map was included within the draft copy 
on file at CAR, so the location of this excavation is not presented on Figure 3.

The next year, Anne Fox with the Center for Archaeological Research excavated a test unit at the northwest corner of a chimney where it meets the exterior wall of Room 4 (Fox 1999). This unit measured 5-x-3 ft. and reached a depth of 32 in. (Figure 3). The chimney was pulling away from the wall so excavation commenced to explore whether an unstable foundation may be contributing to the problem. Fox found the chimney footing ended at $17 \mathrm{in}$. below ground surface and the wall footing ended at $32 \mathrm{in.} \mathrm{below} \mathrm{surface.}$ Contractors excavated the other half of the chimney base during shoring of the chimney. The exact dimensions of the contracted excavations are unreported.

Seven test holes were also excavated during this project (B-1 through B-7 on Figure 3). Bore Hole 1 was placed east of the north end of the church. Bore Hole 2 is not described, but maps indicate that it lay between Bore Holes 1 and 3 east of the church. Bore Hole 3 was placed outside the sacristy door; Bore Hole 4 lay south of the southeast corner of the sacristy; Bore Hole 6 lay off the northwest corner of the carport behind the priest's quarters; Bore Hole 7 was located off the southeast corner of the restored priest's quarters in the compound. Bore Hole 5 is not described either, but appears on a map at the northwest corner of the church (Fox 1999:Figure 4).

Another stabilization project occurred in 1983 at the Tufa House, Room 28. According to Escobedo (1985), the excavation was confined to an area along the exterior walls and under the wooden interior floor. The entire earthen floor was excavated to $18 \mathrm{in}$. below the existing wooden floor except immediately next to the walls. Six excavation units were placed inside the structure and four trenches were dug along the exterior walls (Units A-F). The interior units were not uniform in size but averaged $5 \mathrm{ft}$. 6 in. square. Trenches along the east and west side of the house were $1 \mathrm{ft} .6 \mathrm{in}$. to $3 \mathrm{ft}$. wide and $25 \mathrm{ft}$. long. Northern and southern trenches were $20 \mathrm{ft} .8 \mathrm{in}$. and $19 \mathrm{ft} .6$ in., respectively.

Unit B formed the corner quadrant of the junction of the north and west walls, west of Unit A. Units E and F were placed in the southern section of the house. Units C and D formed the central portion of the east and west walls. Test pits were also excavated in the trenches along the exterior.

CAR returned to Mission San Juan Capistrano in 1986 to determine if construction of a pipeline would impact important archeological deposits (Turner 1988). David Turner supervised excavation of five 1-x-1-m test units opened along the outside of the northern wall. Each unit was excavated to $80 \mathrm{cmbs}$. Monitoring of trenching operations also occurred on the eastern side of the mission. They uncovered a midden 5.5-6.0 ft. deep and 22 to $24 \mathrm{in}$. wide. The location of the trench is not reported but the test units are shown on Figure 3.

In 1992, Anne Fox returned to the mission with CAR to conduct excavations along the eastern wall of the compound in order to investigate the impacts of drainage swales to the archeological record in that location (Fox 1993). Twelve 3 -x-3-ft. units were placed across the area revealing two features associated with the Tufa House (Figure 3).

Kevin Gross, also with CAR, conducted excavations in 1996 to examine an area south of the compound for more drainage construction (Gross 1998). Forty-three shovel tests were excavated at $5-\mathrm{m}$ intervals in areas specified for the proposed 800-ft. drainage channel (Figure 4). The work revealed that the area contained a mixed Colonial period and modern zone.

Diane Cargill of CAR monitored the removal of a service drive and tested for the installation of a new service drive in 1997 and 1999, respectively (Cargill and Robinson 2000). Three 3-x-3-ft. units, 14 shovel tests, and one backhoe trench were excavated in the proposed service drive (Figure 4). The drive is near middens found east and west of the north gate to the compound (Scurlock et al. 1976; Turner 1988). Units 1-3 were dug in six-inch arbitrary levels down to 24 in. below the surface. Unit 2 was dug to 36 in. Shovel tests were 20 to $33 \mathrm{in}$. deep. The backhoe trench was $24 \mathrm{ft}$. long perpendicular to the drive and dug to $32 \mathrm{in}$. No Colonial midden deposits extended into the area.

In October 1998, CAR tested for intact deposits endangered from ensuing trenching for utilities outside the western wall of the compound (Cox et al. 1998). They excavated 10 $1-\mathrm{x}-1-\mathrm{m}$ units and 12 shovel tests. This work revealed many architectural features previously unrecorded. All excavation occurred outside the western wall. Test Units 1-3 were aligned with the proposed utility trench. Unit 1 was $10 \mathrm{~m}$ west of the southwest corner of the chapel. Unit 2 was $10 \mathrm{~m}$ west of Unit 1, and Unit 3 was $10 \mathrm{~m}$ north of Unit 2.

Units 4 and 5 were near a manhole vault in the northern part of the compound. Unit 4 was on the north side of the vault. Unit 5 was on the south side of the vault. Unit 6 was 
seven meters east of the southeast corner of the manhole vault. Unit 7 was $15 \mathrm{~m}$ southwest of the manhole vault. Unit 9 was $12 \mathrm{~m}$ west of the southwest corner of the chapel. Unit 10 was excavated $21 \mathrm{~m}$ west of the southwest corner of the chapel. Twelve shovel tests were placed in 5-m intervals west of the existing Priest's Quarters (Figure 3).

In 1998, NPS hired CAR to monitor installation of buried electrical lines along the south side and front of the present church (Fox and Cox 2000). Shovel testing in the center of mission compound occurred at the request of NPS in preparation for re-interment ceremonies of Mission Indian remains on the east side of the compound. Eleven shovel tests were excavated in three north-south rows $20 \mathrm{~m}$ apart. Two other tests centered between these rows. The tests averaged 20-25 $\mathrm{cm}$ deep. Shovel testing showed the quadrangle was disturbed. A trench was also excavated to install a buried electrical line. The ditch was mechanically excavated with a small hand-held trenching machine to 6 in. wide and 18 in. deep (Figure 3).

In 1999, CAR returned the remains of 103 to 125 individuals to the Archdiocese Director of the Old Spanish Missions for reburial (Tomka and Zapata 2001). CAR also located and monitored the excavation of two reburial areas inside the Old (Late Colonial) Church Room 26, at the southeast end of the compound. Inside the church, areas at the western end and the center, chosen for reburial, were therefore chosen for re-excavation. (This report notes that Schuetz 1968, Figure 24 shows an inaccurate scale of excavations.) Within the church, Area 1, excavated near the doorway, measured $13-\mathrm{x}-13 \mathrm{ft}$. The northwest corner was unexcavated to allow foot passage. Area 2, located near the center, measured $10-\mathrm{x}-13 \mathrm{ft}$. Area 1 was mechanically excavated to $4 \mathrm{ftbs}$. Area 2 was hand excavated to four feet below surface (Figure 3).

Also in 1999, the Center for Archaeological Research monitored the excavation of 75 cedar posts along the west lane of Mission Road (Padre Drive). These excavations encountered a lateral ditch to the main irrigation ditch (Figure 4). Each posthole was excavated by mechanical auger to 38 in. then hand-excavated to 40 in. (Cox 1999).

Test excavations were performed for NPS again in 2005 prior to stabilization to include the installation of an impermeable barrier surrounding the convento (Córdova et al. 2005). The barrier was to be six inches deep adjacent to the walls sloping to $18 \mathrm{in}$. below surface eight feet from the walls. The barrier would surround the convento building and extend around the southwest corner of the compound along the west and southern walls of Rooms 19, 20, 21 , and 22 .

NPS required five 1-x-1-m units. Three were at the bases of the east, north, and west walls of the convento. The fourth was against the outside wall of Rooms 21 and 22. Units were to reach $60 \mathrm{cmbs}$ in three arbitrary 20 -cm levels. A final unit was next to a buttress along the west side of the convento to find the depth of the buttress base (Figure 3).

\section{Historical Background}

Spain instituted the Spanish missions in order to protect Spanish interests in Texas and to Christianize and assimilate the indigenous populations to Roman Catholic and Spanish customs. The process also served to populate Texas with converts rather than reluctant immigrants from Spain. Politically, the missions and presidios served to protect the eastern frontier from French-occupied Louisiana by building missions and presidios in the hinterlands other Spanish colonists refused to inhabit. The missionaries and soldiers who settled these areas assembled the native population, forced them into sedentary lives, taught them European traditions, and put them to work serving the missionaries in the fields and inside the compound.

Mission San Juan Capistrano was one such mission established in 1716 as San José de los Nazonis, to defend against French encroachment from the east. In 1731, Mission San Juan and the other east Texas missions moved to the San Antonio area after the French threat subsided and the operation costs became prohibitive. The earliest years of the mission in San Antonio endured disease and attack from the bordering indigenous populations. Both problems waned after 1737 and the missions saw the native population rise despite smallpox epidemics between 1748 and 1751 (Carlson 1994:72-85). By 1750, the mission was successful enough to begin construction of the mission compound. Schuetz reports construction of the friary, granary, and stone church in 1756 (Schuetz 1968).

Various inventories made by visiting priests give us an idea of the prosperity of the mission and the structures built in the mission compound through the years. In 1762, Fr. Delores recorded the construction of a convento including a church (Room 26) and sacristy, four cells, refectory, kitchen, workshop, porter's lodge, a full granary, and reported plentiful livestock in the fields. Most homes were reportedly of thatched roofs, a temporary construction 
until stone houses could be built (Cox et al. 2001). The bounty of plentiful orchards, gardens, and Rancho de Pataguilla, the mission sheep and cattle farm, supplied areas from Louisiana in the east to Coahuila, Mexico in the south.

Another inventory was taken of the mission in 1772 during a political shift over control of the missions. This document describes a replaced church, a friary with four rooms, a guesthouse, two workshops, an assignment room, an auxiliary kitchen, a community room, 15 new houses, and plans for a new pueblo (Cox et al. 2001).

In 1786, Fr. Lopez reports a third building inventory describing the quadrangle, surrounded by a wall. Near the convento, another church and sacristy were in progress but temporarily stopped. Ivey reports this might be the unfinished church on the east end of the compound begun between 1772 and 1779 (Ivey et al. 1990:184).

Essential to the success of the mission was regular supplies, despite its goal of self-sufficiency. The lack of regular supplies contributed to the low population of Texas and exacerbated problems with raids and disease.

Mission San Juan Capistrano was partially secularized in 1794, at which time the mission land and livestock were divided among the native residents (Schuetz 1968:54). The mission temporarily lost its missionary; the resident priest from Mission Espada, oversaw the religious activities of Mission San Juan during this period (Habig 1976:178). Complete secularization occurred in 1823 and all mission activities ceased. In 1831, all the remaining properties other than the chapel were sold at auction and underwent many stages of division and ownership. During the 1850s, the Tufa House and other structures were constructed and demolished before William Corner mapped the ruins in 1890 (Cox et al. 2001).

Father Francis Bouchu was very important to the preservation of both Mission San Juan and Mission Espada. He spent most of his tenure as parish priest at Mission Espada, but before he settled there, he made his home at Mission San Juan. He is credited with building a house that still stands on the eastern wall of the San Juan compound, re-roofing, and repairing the chapel for services in 1877 . He eventually moved his residence to Mission Espada in 1885 where he also undertook restoration projects on his own (Fisher 1998:82).
The next year, in 1886, a hurricane tore the roof off the chapel at San Juan. It was not repaired until 1907, after the death of Father Bouchu, when architect Leo Dielmann made repairs to both Mission Espada and the chapel at Mission San Juan (Fisher 1998:82). Services began once again in 1909 under the direction of the Claretian order. The diocesan clergy took care of the chapel after the Claretians until the Archdiocese of San Antonio began buying back individually owned properties. Schuetz reports the entire mission was in control of the Archdiocese by 1933 (Schuetz 1968:67)

In 1972, Mission San Juan Capistrano was added to the National Register of Historic Places and, in 1980, was opened as a park under the control of the National Parks Service.

\section{Methodology}

CAR exposed the chimney footing and part of the exterior north wall of Room 4 in Test Unit 1, a 1-x-1-m (3.28-x-3.28-ft) test unit, $30 \mathrm{~cm}(11.81 \mathrm{in})$ east of the chimney (Figure 8). The unit datum was placed north of the unit. All elevations were taken from the ground surface at this point. Ground surface rises toward the building so elevations below surface were approximately $5 \mathrm{~cm}$ deeper near the north wall. Most of the 1-x-1-m unit was excavated to $70 \mathrm{cmbd}(2.3 \mathrm{ft})$. In order to find the bottom of the concrete footing supporting the chimney, the northwest corner (40-x-60 cm; 1.31-x-1.97 in) was excavated deeper to $100 \mathrm{cmbs}(3.28 \mathrm{ft})$. We also expanded $40 \mathrm{~cm}$ of the northwest corner $40 \mathrm{~cm}$ to the north in Test Unit 2 to locate the corner of the concrete footing. The units exposed $117 \mathrm{~cm}(3.84 \mathrm{ft})$ of the chimney footing (north to south) and $100 \mathrm{~cm}(3.28 \mathrm{ft})$ (east to west) of the north wall foundation (Figure 9).

Excavation of Unit 1 occurred in $10-\mathrm{cm}$ levels within the $1-\mathrm{x}-1-\mathrm{m}$ unit and all matrix was screened through $1 / 4-\mathrm{in}$. hardwire cloth. We did not screen the expanded $40-\mathrm{x}-40-\mathrm{cm}$ area (Unit 2) or excavate it in levels. This was within an area reported to have been excavated by backhoe (Fox 1999). Artifacts were collected in sample bags, which were labeled by provenience, and taken to the CAR laboratory for processing, analysis, and curation preparation. CAR field personnel recorded observations of each level on level forms. Profile drawings were also made of the foundation and chimney as exposed in the excavation units. These and all photographs of the excavation are permanently curated at CAR. Previous excavation at this location recorded 


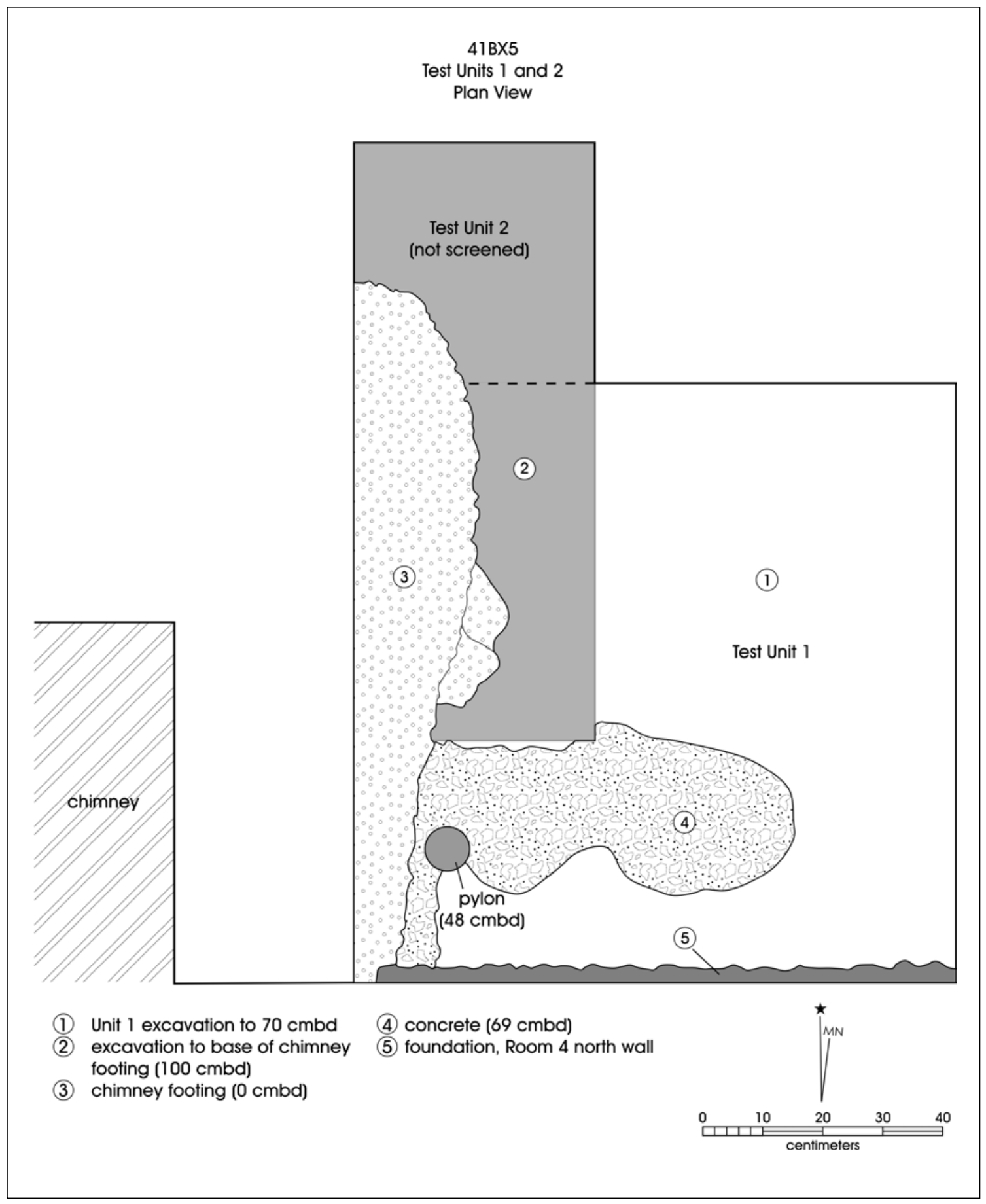

Figure 8. Plan view drawing of Test Unit 1 at $70 \mathrm{cmbd}$, the bottom of the excavation. 


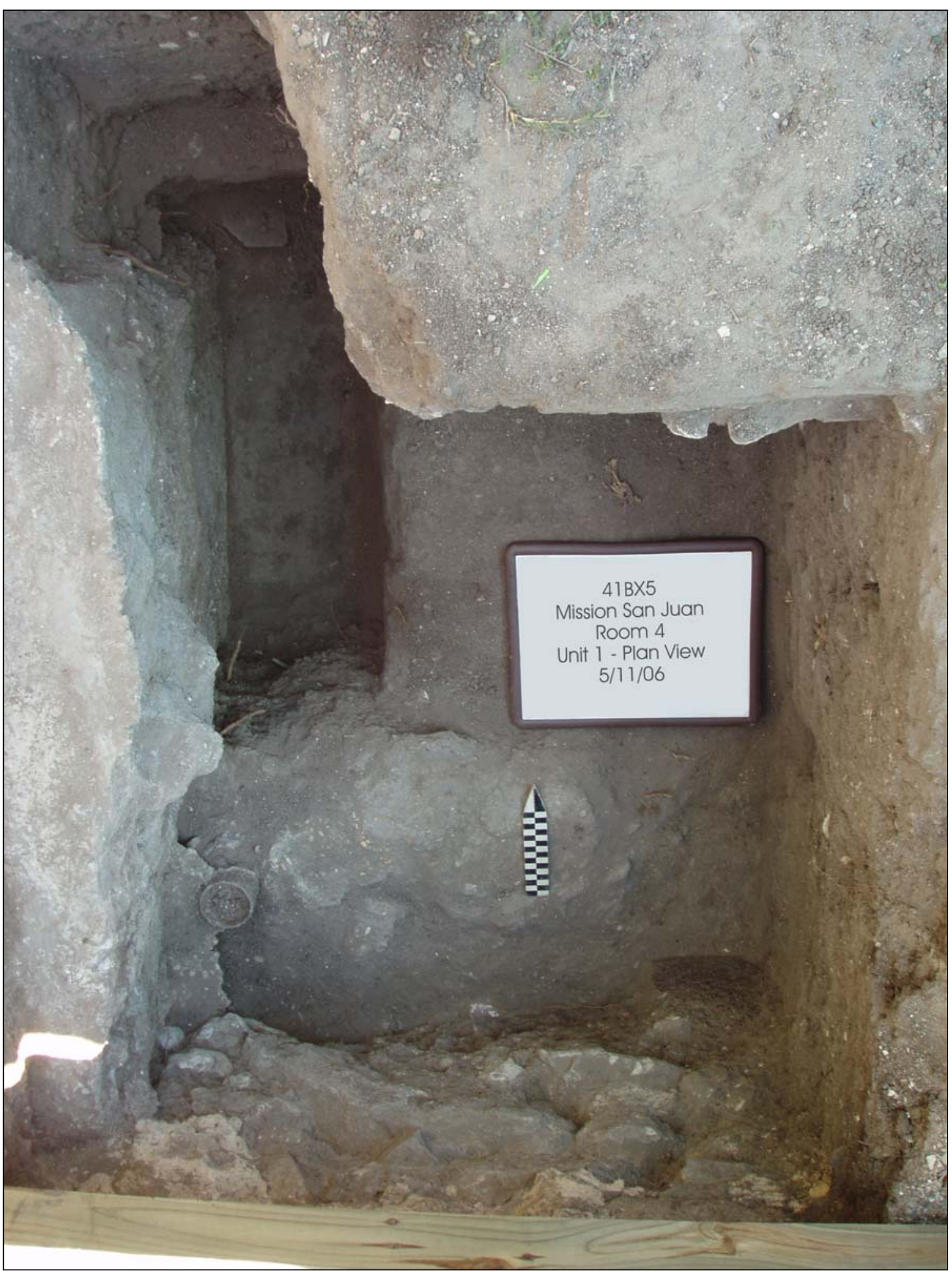

Figure 9. Photograph of final excavation of Test Unit 1. 
the foundation $81.27 \mathrm{~cm}$ (32 in) below the ground surface (Fox 1999).

Artifacts processed in the CAR laboratory were washed, air-dried, and stored in 4-mil, zip-locking, archival-quality bags. Organic materials and materials needing extra support were double-bagged. Acid-free labels were placed in all artifact bags. Each label contains provenience information and a corresponding lot number and is written in archival ink, pencil, or laser printed. Ceramics were labeled with permanent ink over a clear coat of acrylic and covered by another acrylic coat. In addition, a small sample of unmodified debitage from each lot was labeled with the appropriate provenience data. Artifacts were separated by class and stored in acid-free boxes identified with standard tags. Field notes, forms, photographs, and drawings were placed in labeled archival folders. Photographs, slides, and negatives were labeled with archivally appropriate materials and placed in archival-quality sleeves. All field forms were completed with pencil. Any soiled forms were placed in archival-quality page protectors. Ink-jet produced maps, illustrations or other graphics were also placed in archivalquality page protectors to provide against accidental smearing due to moisture.

Subsequent to proper analyses and/or quantification, and as stated in the Texas Antiquities Committee permit application Scope of Work, artifacts possessing little scientific value were discarded pursuant to Chapter $26.27(\mathrm{~g})(2)$ of the Antiquities Code of Texas.

\section{Production of the Site Map}

The site map of Mission San Juan Capistrano structure and archeological excavations was redrawn to aid scholars and investigators who may excavate on the grounds and managers in charge of resource protection. For the map's production, a thorough literature search was undertaken, returning to original maps and documents for each project reported. The most complete map we have is Smith's WPA map from 1931-1934. Schuetz also mapped rooms she discovered in the convento at the southern end of the plaza. Unfortunately, both these maps most likely have errors. Schuetz reports errors of the WPA restoration. Her drawing in turn does not overlap well with the WPA footprint of the compound. Both maps are included in this report (Figures 5 and 6) and overlaid to illustrate the discrepancies (Figure 7).The maps on which we recorded all excavations is based on the WPA map because it is the most complete and corresponds somewhat with modern aerial photographs.
This, along with a table of excavation showing years of work, agency, report reference, location, and dimensions of groundbreaking work when reported, will identify the locations of previous excavations as close as possible (Appendix A:Table A-1).

\section{Results of Current Excavations}

Ford, Powell, and Carson, Inc. was interested in determining the parameters of the foundation and the chimney footing of Room 4. The excavation revealed the surface of the chimney footing at $12 \mathrm{cmbs}$ (4.72 in) and the edge $45 \mathrm{~cm}$ east of the chimney. The base of the chimney footing is at $100 \mathrm{cmbs}$. The height of the footing (top to bottom) is $88 \mathrm{~cm}$ (34.5 in) (Figure 10). At $48 \mathrm{~cm}$ (1.57 in), we uncovered a pylon set in concrete supporting the chimney footing. The center of this pylon is approximately $20 \mathrm{~cm}$ north of the foundation and $5 \mathrm{~cm}$ from the edge of the footing (Figures 8 and 9). At $69 \mathrm{cmbs}$, excavations uncovered overflow concrete across the northern portion of the unit from the pylon installation (Figure 8). Excavations revealed the base of the foundation at $60 \mathrm{cmbs}$ (Figure 11). Mortar and rock crumbled from the foundation despite careful excavation. There is no recent footing supporting the foundation (Figure 12).

Though previous documentation described test units at the juncture of the north and west walls of Room 4 (Schuetz 1969), at the northwest corner of the chimney, and in backhoe trenches across the northern face of the chimney (Fox 1999), we had no specific provenience for some of these excavations mentioned and assumed some intact soils still existed near the western corner of the chimney at the wall. Our excavations revealed modern trash mixed with artifacts to $70 \mathrm{cmbs}$. The trench excavated for the pouring of the concrete footing could have caused these results. Because the concrete was poured into the trench, which acted as a mold, disturbed soils away from the footing were likely caused by Schuetz's excavation and backfilling or other unrecorded excavations here. Below $70 \mathrm{cmbs}$ in Test Unit 1, the matrix was compact and void of both artifacts and modern trash.

\section{Artifacts Analysis}

Though disturbed, the fill in Test Unit 1 contained a moderate number of artifacts including bone, ceramics, building materials, bottles, and glass wares. Without stratigraphy, relative dating of the deposits with artifacts is impossible. The collection of artifacts from our single test 


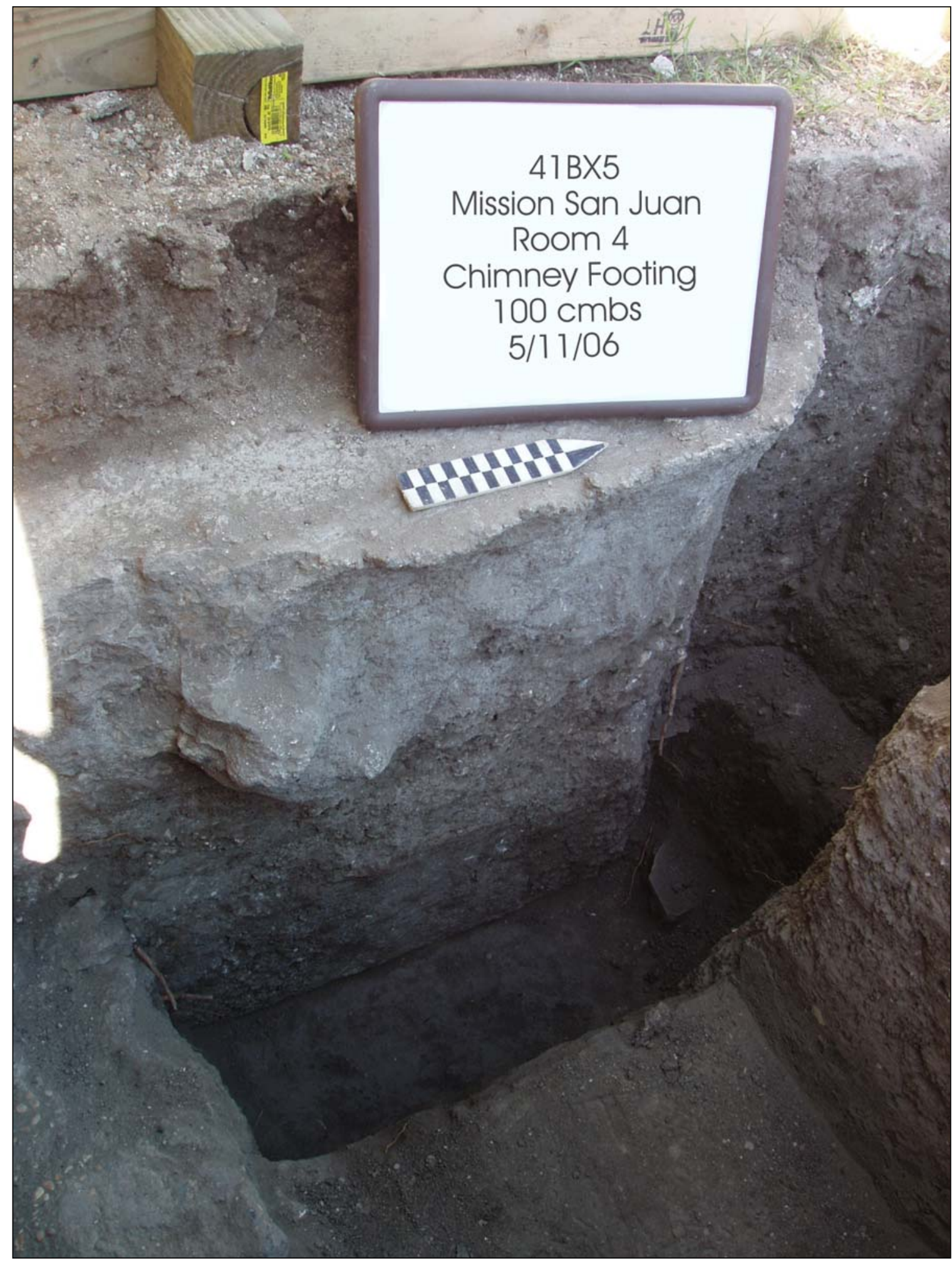

Figure 10. Photograph of the chimney footing exposed in Test Unit 1. 


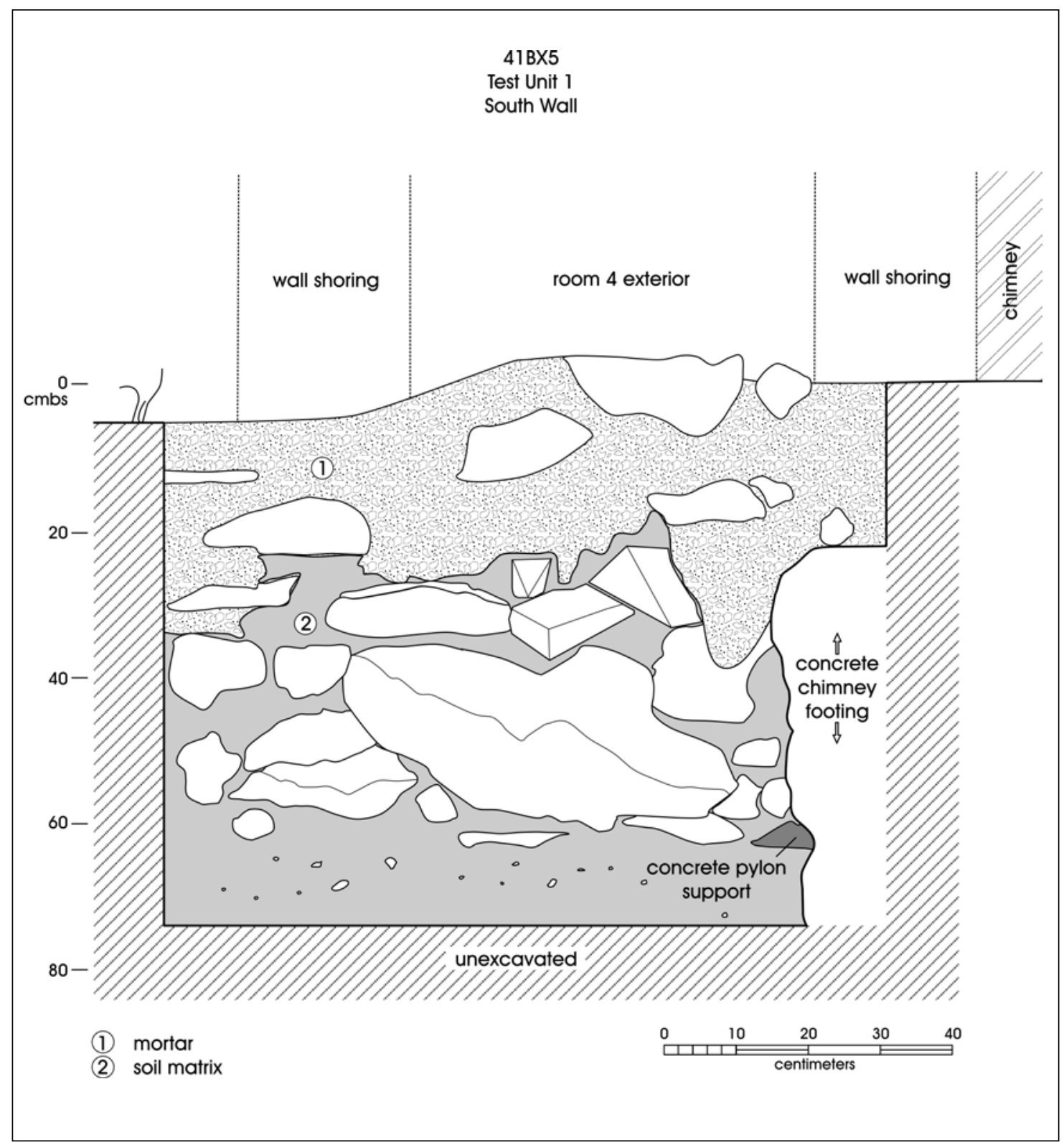

Figure 11. Profile drawing of the foundation. 


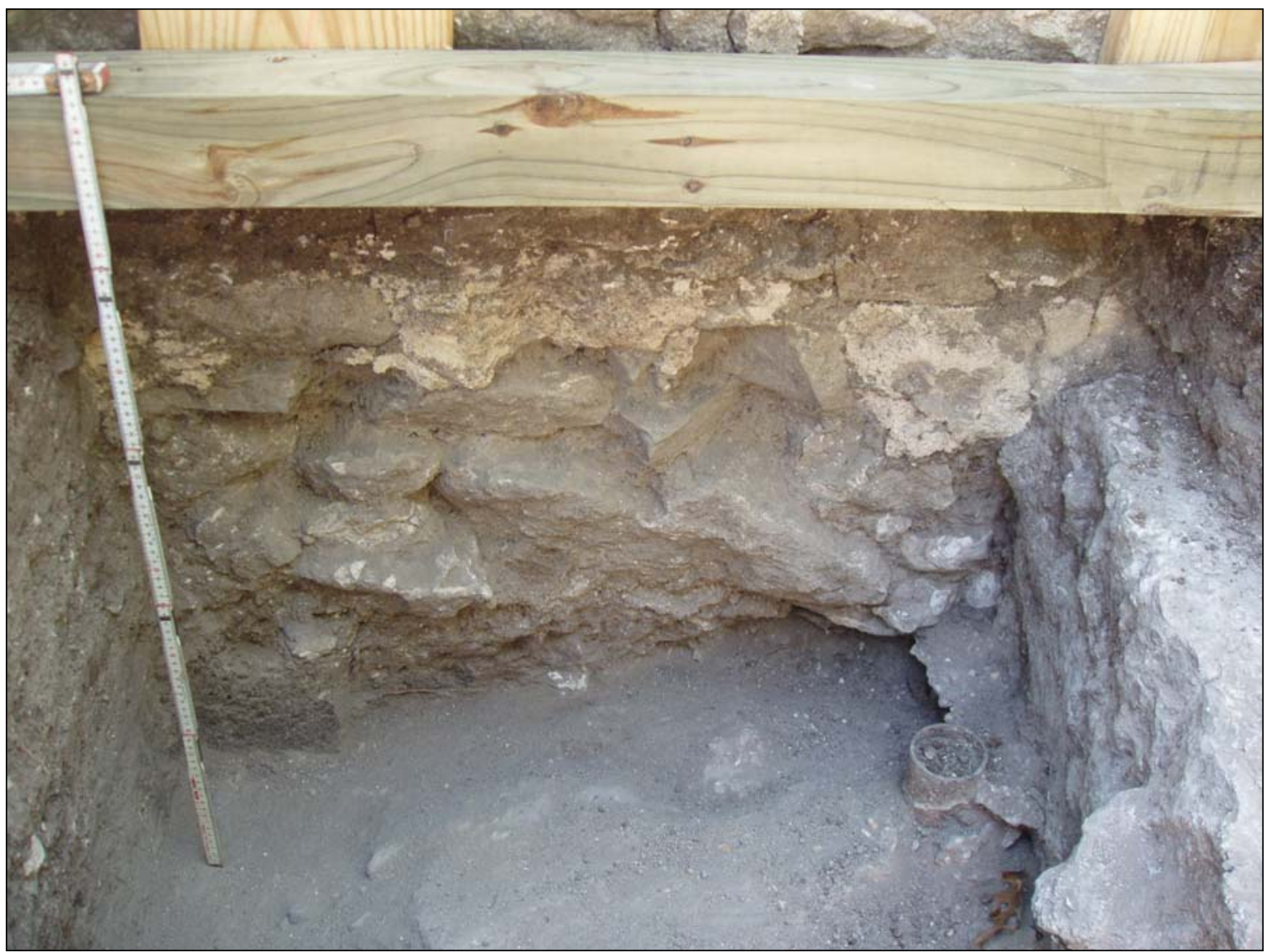

Figure 12. Photograph of the foundation.

unit resembles that recovered from previous excavations and does not add to, but confirm our knowledge of life at Mission San Juan Capistrano.

\section{Ceramic Type Analysis}

\section{Kristi M. Ulrich}

Ceramics found in the archaeological record serve as one of the best examples of the missions' dependence on imports from the rest of the world. The origin of the ceramics gives us the geographical scope of the missionaries' contacts with the world outside the mission walls and their reliance on locally made wares in times of limited imported supplies. Ceramic sherds can be very helpful in the dating of stratified deposits, though in this instance, stratified deposits were not present. When information such as manufacturing technique, decoration, or place of origin can be determined, ceramic sherds provide insight to the activities and economics of a particular site. Though the deposit is disturbed, the sherds collected represent twelve types of unglazed, tin-glazed, lead-glazed, white, and annular wares from the eighteenth and nineteenth centuries (Table 1).

The ceramic sherd collection recovered from the excavation conducted on the outer wall of Room 4 totals 139 specimens. These sherds represent the Native tradition as well as the later Mexican imported wares. Previous investigations indicate that the area had been trenched and excavated to allow for stabilization activities conducted in 1983 (Fox 1999). The following discussion identifies the types of ceramics recovered from the excavations.

\section{Unglazed Wares}

A total of 80 unglazed ceramic sherds were recovered from Unit 1 . The majority of the unglazed wares are locally made Goliad ware. One fragment of the 80 sherds was too small and sandy for identification. 


\section{Goliad Ware}

The type is identified as representing a possible continuation of the Toyah Phase ceramic tradition produced by the local native population (Black 1986). Goliad wares are hand made utilizing the coil technique, and are bone-tempered earthen wares that have been low fired. Typical vessel forms include bowls, jars, bottles, and large water storage vessels. Goliad ware vessels were produced throughout the mission period and possibly manufactured by local women well after secularization. A total of 76 Goliad ware fragments were collected from the unit. Level $5(40-50 \mathrm{cmbs})$ produced the largest quantity of sherds. All levels produced several fragments of Goliad.

\section{Tonalá Burnished}

One fragment of Tonalá Burnished ware was encountered in Level $1(0-10 \mathrm{cmbs})$. A grey paste and distinct sweet, earthy smell when wet characterizes Tonalá Burnished vessels. They are painted with elaborate designs in black, tan, and red tones, before being polished to a high shine when in the leather hard state. Tonalá Burnished wares were produced from the early seventeenth century to the early nineteenth century, possibly in Tonalá, Mexico (Fox and Ulrich 2005).

\section{Unglazed Wheel-Thrown}

Two fragments of an unglazed, wheel-thrown ceramic were recovered from Levels $3(20-30 \mathrm{cmbs})$ and $4(30-40 \mathrm{cmbs})$, respectively. Often unglazed, wheel-thrown sherds are identified as Valero ware, but the sherds recovered during this investigation do not provide enough information to safely class them as such.

\section{Tin-Glazed Wares}

Thirteen tin-glazed ceramic sherds were recovered from Unit 1. The majority of the tin-glazed ceramics encountered were produced in Mexico and transported to the colonial outpost via mule trains. Tin-glazed wares were not common among the neophytes, rather were reserved for use by the padres and visiting dignitaries. One unidentified, decorated fragment of tin-glazed ware is included in the thirteen fragments recovered.

\section{Undecorated Tin-Glazed Wares}

Seven fragments of undecorated, tin-glazed wares were recovered during the course of the excavation. Undecorated sherds are not usually lacking decoration purposefully; rather, they are fragments of larger decorated vessels that happen to lack the applied decoration.

\section{Puebla Blue on White}

Puebla Blue on White is one of the more common types of tin-glazed wares recovered from Spanish Colonial sites in Texas. On fragments that tend to have larger examples of the decoration, a specific sub-category is assigned. In the case of the two fragments recovered from this project, the size of the sherd and decoration on the surface did not allow for placement in a more specific category.

The ceramic type is characterized by the white enamel glaze on both the interior and exterior of the vessel and accented with blue decoration. Typical decoration motifs consisted of floral designs, dots, lobes, and bands. Puebla Blue on White was produced throughout the eighteenth century (Fox and Ulrich 2005).

\section{Tumaccacori Polychrome}

Tumaccacori Polychrome is distinctive with the blue enamel surface on both the interior and exterior of the vessel. The color of the enamel is reminiscent of a robin's egg. Decoration on these vessels usually consists of linear floral designs below the rim. Tumaccacori Polychrome has been recovered from Spanish sites utilized late in the colonial period. The ceramic type was possibly produced in Puebla, Mexico during the early to mid-nineteenth century (Fox and Ulrich 2005). One body sherd was recovered from the excavations during the course of the project. The sherd was located in Level 3 (20-30 cmbs).

\section{Guanajuato Polychrome}

The fragments of Guanajuato exhibit a terra cotta colored paste, rather than the buff to light tan noted in other types. The white enamel on the interior and exterior surfaces of the vessels tends to have a green tint. Decorations on this type consist of geometric motifs in green, yellow, rust, and brown. It is believed that this type was produced in Guanajuato, Mexico during the early to mid-nineteenth 
Table 1. Unit 1 Ceramic Types

\begin{tabular}{|c|c|c|c|c|c|}
\hline Surface & Type & Colonial & English & Native & Total Count \\
\hline Unglazed & $\begin{array}{l}\text { Goliad } \\
\text { Tonalá Burnished } \\
\text { Unknown Sandy Paste } \\
\text { Unglazed Wheel-Thrown }\end{array}$ & $\begin{array}{l}1 \\
1 \\
2\end{array}$ & & 76 & \begin{tabular}{r|}
76 \\
1 \\
1 \\
2
\end{tabular} \\
\hline \multicolumn{2}{|c|}{ Unglazed Total } & 4 & & 76 & 80 \\
\hline Tin-Glazed & $\begin{array}{l}\text { Guanajuato Polychrome } \\
\text { Puebla Blue on White } \\
\text { Tumaccacori } \\
\text { Undecorated } \\
\text { Unknown }\end{array}$ & $\begin{array}{l}2 \\
1 \\
1 \\
7 \\
1\end{array}$ & & & $\begin{array}{l}2 \\
2 \\
1 \\
7 \\
1\end{array}$ \\
\hline \multicolumn{2}{|c|}{ Tin-Glazed Total } & 13 & & & 13 \\
\hline Lead-Glazed & $\begin{array}{l}\text { Annular Ware } \\
\text { Black Lusterware } \\
\text { Galera } \\
\text { Green Lead-Glazed } \\
\text { Immature Glaze } \\
\text { Sandy Paste } \\
\text { Undecorated White Earthenware } \\
\text { Unknown }\end{array}$ & $\begin{array}{c}3 \\
16 \\
2 \\
3 \\
10 \\
\\
7\end{array}$ & 1 & & \begin{tabular}{r|}
1 \\
3 \\
16 \\
2 \\
3 \\
10 \\
4 \\
7 \\
\end{tabular} \\
\hline \multicolumn{2}{|c|}{ Lead-Glazed Total } & 41 & 5 & & 46 \\
\hline \multicolumn{2}{|l|}{\begin{tabular}{|l} 
Grand Total \\
\end{tabular}} & 58 & 5 & 76 & 139 \\
\hline
\end{tabular}

century (Fox and Ulrich 2005). We recovered two fragments of Guanajuato Polychrome from Level 3 (20-30 cmbs).

\section{Lead-Glazed Wares}

In comparison to the tin-glazed wares, many of the lead-glazed wares acted as utilitarian vessels, utilized in storage, cooking, and service. Like the tin-glazed wares, leadglazed vessels were imported to the Texas frontier. Of the 46 lead-glazed sherds recovered, seven were unidentifiable. Three of the sherds exhibited an immature glaze.

\section{Sandy Paste Lead-Glazed Wares}

A total of 10 Sandy Paste Lead-glazed sherds were encountered during excavations. The fragments were recovered from Levels 1, 3, 4, 5, and 6. These sherds have a very sandy paste, with a clear to yellow glaze on at least one of the surfaces. The vessels are wheel-thrown and fired in conventional kilns. The sherds tend to be thick, possibly to reduce breakage during transport. Sandy-paste lead-glazed wares were produced throughout Mexico during the eighteenth century (Fox and Ulrich 2005).

\section{Green Lead-Glazed Ware}

This type is similar to the previously discussed Sandy Paste Lead-glazed type, but the glaze appears as green rather than clear. Green Lead-glazed wares are sandy-pasted, thick-walled vessels used as storage containers, cooking vessels, and service pieces. The vessels were imported from Mexico during the eighteenth century. Two fragments of this type were recovered from Level $4(30-40 \mathrm{cmbs})$.

\section{Galera Ware}

Sixteen sherds of Galera ware were recovered during the course of the investigation. These fragments were encountered in Levels 3, 4, 5, and 7. This type was produced utilizing the wheel and fired in kilns. The vessels tend to have rather thin walls. The surfaces are glazed with a clear glaze that accents the orange color of the clay. Decoration consists of brown/black brush strokes as well as cream and 
green dots. Typical vessels manufactured included serving dishes, chocolate pots (chocolateras), and bean pots. Galera appears to have been prominent at Texas sites during the early eighteenth to mid-nineteenth century (Fox and Ulrich 2005). Similar vessels are produced today.

\section{Black Lusterware}

Three fragments of Black Lusterware were encountered in Level $1(0-10 \mathrm{cmbs})$. The ceramic type is characterized by a buff to terra cotta colored paste, with a thick and shiny black lead glaze. Not much is known about this type of ceramic, but estimated dates of manufacture range from 1750 to 1850 (Fox and Ulrich 2005).

\section{White Earthen Wares}

White earthen wares entered the archaeological record late in Texas. These ceramics began making their way into San Antonio when trade transportation became easier than the mule trains used during the Colonial period. These are high-fired, wheel-thrown vessels with a white paste. Most examples exhibit a clear glaze on interior and exterior surfaces. Testing recovered five white earthenware sherds.

\section{Undecorated White Earthen Ware}

Four sherds of Undecorated White Earthen ware were collected. Two were encountered in Level $1(0-10 \mathrm{cmbs})$ and two from Level $2(10-20 \mathrm{cmbs})$. These sherds exhibit no decoration, though it is possible that they are fragments of a decorated vessel. White earthen wares are common in San Antonio after the start of the nineteenth century. Despite disturbance, the White Earthen ware sherds come from high in the stratigraphy.

\section{Annular Ware}

One fragment of Annular ware was recovered from Level $1(0-10 \mathrm{cmbs})$. This is decorated, white earthenware characterized by slip application in various-sized bands. Before firing, the vessel is attached to a lathe and the slip applied using a special applicator. Other designs include the cat's-eye and mocha slips. Typical colors used include a rust orange, blue, white, yellow, green, grey, black, and various shades of brown. Annular ware became popular in San Antonio during the early to mid-nineteenth century.

\section{Goliad Ware Analysis}

Presently, all mission-derived ceramics are lumped into a single catchall: Goliad ware or type. This occurs even in the face of the fact that Goliad collections derive from many Spanish Colonial sites throughout Texas. In many cases, ethnically distinct groups inhabited these sites from 15 to 60 years, sometimes longer, during the eighteenth and early nineteenth centuries. Given the factors of geographic location, ethnic composition of populations, and length of occupation, we expect that a significant degree of variation exists within the Goliad type. Variability in many of the observable characteristics of the sherds may be somewhat difficult to explain given that natural composition variability within local clays, technological variability related to form and function, and variability related to cultural/ethnic traditions of manufacture could all contribute to the pattern. Regardless, only a limited detailed knowledge of the characteristics of Goliad wares exists to this day. Specific suggestions from the ethnohistoric record (Cardenas 1783) include the idea that Aranama potters from Mission Espíritu Santo may have made and furnished wares to other missions including Rosario and Refugio, creating the need to determine if this claim is true (Perttula 2002; Ricklis 1999, 2000). To add to the currently available characterization of Goliad ceramics, we examined the collection of sherds encountered at Mission San Juan Capistrano during this project.

\section{Analytical Methods}

We examined a collection of 76 Goliad ceramic sherds from Mission San Juan during the course of the study. The ceramic assemblage included a collection of sherds collected during the excavation of the unit on the outer portion of Room 4 where the chimney wall collapsed. Each ceramic sherd was measured and weighed, and the formal, stylistic, and technological attributes were recorded (Appendix B: Table B-1). Only sherds that were larger than $1 \mathrm{~cm}(10 \mathrm{~mm})$ in one dimension were utilized for this study. Of the $76 \mathrm{Goliad}$ sherds collected, 43 met the minimum dimension criteria.

The collection of Goliad sherds was analyzed without reference to stratigraphy. The artifacts recovered during the course of investigations appeared in disturbed soils, though the occupation dates of the mission (1731-1793) provide enough constraints to present the assemblage as one sample. The information gathered through this analysis will be added to a comparative database consisting of samples of Goliad ware from other Spanish Colonial sites. 


\section{Formal Attributes}

Formal attributes recorded included vessel, lip, and rim form, and wall thickness. Body and base sherds of native ceramics usually convey very little information concerning the vessel form; therefore, rim sherds were the only fragments examined to determine vessel form. Rim form was recorded as everted, inverted, straight, or unknown. Typically, vessel forms can be inferred based on the rim sherd form and degree of curvature. Everted rims are characteristic of ollas and jars. Inverted rims usually indicate neck-less jars and certain bowl forms. Straight rims are indicative of tall jars and bottles. Shallow and deep bowls are distinguished by the degree of curvature on the rim. A downward curve greater than 25 degrees from a perpendicular plane can be classed as a shallow bowl, whereas a degree of curvature less than 25 degrees are considered a deep bowl (Ricklis 2000).

Lip form was another attribute recorded for rim sherds. Three lip form categories were used: pointed, flat, and rounded. Lip form may be an indicator of the style of an individual or of cultural groups of potters. Orifice diameter was recorded for rim sherds that were large enough to determine the rim arc. To determine vessel orifice diameter, the sherd was placed rim down on a concentric circle template, positioning the sherd so that the lip rested on the flat surface. The concentric circle template was composed of graduated $1-\mathrm{cm}$ rings, and the rim sherd was fitted to the closest diameter.

Thickness of each sherd was taken in millimeters at four places on each sherd using digital calipers. In general, ceramic analysts assume that thicker vessel walls increase the impact resistance of the vessel (Braun 1981; Rice 1987; Skibo 1995). Such a characteristic may be advantageous for vessels that are often moved and therefore it may correlate with high levels of mobility. Similarly, it is assumed that thinner walls increase thermal shock resistance, that is, the ability to withstand repeated heating and cooling before cracking. This characteristic may in turn be significant for vessels that are primarily used for cooking (Rice 1987; Ulrich 2004:46).

\section{Technological Attributes}

Technological attributes refer to characteristics associated with the preparation of clays and the firing of the vessel. Information recorded included the type of aplastic inclusions, the relative quantity of the inclusions, and the firing atmosphere of the vessel.
Aplastic inclusions consist of particles present in the clay body. Aplastic inclusions seen in the sample include crushed bone, sand grains, and burned sandstone fragments. During the analysis, inclusions were grouped into the following categories: bone, bone/sand, bone/sandstone and sand. In addition, each sherd also was examined for other materials such as sandstone, and their presence was noted.

While it is assumed that bone is a purposeful tempering additive, in the case of some constituent elements present in ceramic sherds (e.g., sand) it is difficult to determine whether the substance represents a purposefully added tempering agent or is contained within the parent source of the clay (Rice 1987). The density of sand within the sherds examined varied, therefore did not indicate a purposeful addition of the sand to the clay.

As part of the analysis, each sherd was freshly broken allowing for a clean view of the interior of the sherd. The sherd was examined under $40 \mathrm{X}$ magnification to determine the type and density of the aplastic inclusions present. In keeping with the guidelines set by other investigations concerning Toyah (Black 1986), Rockport (Ricklis 1995), and Goliad ceramics (Ricklis 2000), presence of inclusions at less than five percent of the clay body were considered sparse, between five percent and 25 percent was considered moderate, and abundant was greater than 25 percent.

The color of the interior surface, exterior surface, and core of the sherds were examined to help determine the firing atmosphere of the vessel. Colors that fell in the range of buff to red-orange were recorded as oxidized. If the sherds contained shades of gray to black, they were recorded as reduced. Fire clouding, the result of uneven firing, vessels touching each other or organic materials in contact with the vessel during firing, were also recorded as a firing atmosphere attribute. The firing atmosphere was noted as zoned when the core of the sherd exhibited evidence of both oxidized and reduced atmospheres.

\section{Stylistic Attributes}

Stylistic attributes refer to surface treatments and decorations present on the ceramic sherds. Surface finish and decoration were the two types of stylistic attributes recorded. Surface finish categories looked for included smooth, and rough; decorative finishes included application of organic coating (indicated as asphaltum), polish, residue and smudging. The presence of these stylistic attributes 
was recorded for both the interior and exterior surfaces of all sherds.

\section{Discussion of Results}

The results of the attributes recorded are presented in the following paragraphs. These results have been compared to another collection from Mission San Juan discussed in Córdova et al. (2005).

\section{Vessel Forms}

Of the 43 sherds examined, nine sherds were rims. The rims were examined for a few more criteria than the body sherds. Vessel forms were difficult to determine for these sherds. Four of the rim sherds are believed to have originated from jars. Another four appear to have been fragments of shallow bowls. The last sherd has characteristics similar to a deep bowl. These results slightly differ from the Córdova et al. (2005) analysis, which had no examples of jars, but a moderate number of deep bowls.

\section{Thickness}

Thickness was recorded at four sites on each sherd surface. The measurements were then averaged to produce the mean thickness for each sherd. The average thickness was utilized when examining the trends in the collection. The mean thickness of the total collection is $6.49 \mathrm{~mm}$. The collection was also divided by sherd type. The mean thickness of the rim sherds is $5.94 \mathrm{~mm}$, while the body sherds exhibited an average thickness of $6.63 \mathrm{~mm}$. It appears that this collection exhibits slightly thicker sherds than the assemblage examined in Córdova et al. (2005) in both the rim and body sherds. This thickness difference may be explained by methodological differences. In the 2005 study, sherd thickness was determined by measuring one point on each sherd rather than by averaging four measurements as done during the current study.

\section{Aplastic Inclusions}

Aplastic inclusions noted in the paste of the sherds include crushed bone, sand, and small fragments of burned sandstone. Crushed bone was present in 40 (93 percent) of the sherds examined; 63 percent of these utilized bone as the sole tempering agent. Fourteen percent exhibited both sand and crushed bone in the paste. Sixteen percent exhibited crushed bone with flecks of burned sandstone.
The remaining three sherds ( 7 percent of the collection) exhibited sand as the only aplastic inclusions.

It is difficult to determine whether sand or the burned sandstone were purposely added tempering agents. The clays utilized may contain these inclusions naturally. Crushed bone, on the other hand, was added to the clay matrix to aid in the vessels' heat and shock resistance. In the sherds that exhibited crushed bone as the only tempering agent, 37 percent exhibited an abundant amount of bone in the paste. Fifty-six percent of the solely bone tempered sherds exhibited a moderated amount of the crushed bone. The remaining seven percent contained a sparse amount of bone. The six sherds that contained both bone and sand exhibited abundant bone, but sparse sand inclusions in one fragment; abundant sand in one, but sparse sand in another; two contained a moderate amount of both sand and bone in the matrix; one fragment exhibited moderate bone, but sparse sand inclusions; and one sherd contained a sparse amount of bone and sand. Of the seven sherds that contained bone and sandstone, three have moderate amounts of the aplastic inclusions. The remaining four contained sparse amounts of bone and sandstone.

\section{Firing Atmosphere}

Goliad wares were fired using a traditional open firing technique rather than utilizing a kiln. The firing atmosphere was determined by examining the surfaces and core of each sherd. If the color ranged from red-orange to buff, the sherd was recorded as fired in an oxidizing atmosphere, with plenty of oxygen in the atmosphere. If the colors ranged from brown to black, the vessel was subjected to reduced firing, which results from a lack of oxygen in the firing atmosphere. Similar to the collection analyzed in Córdova et al. (2005), the highest percentage of sherds exhibited reduced cores (44 percent); oxidized cores followed at 37 percent, and 19 percent exhibited zoned cores. The interior surfaces of the sherds had a greater tendency towards oxidized firing atmosphere (63 percent), with reduced atmosphere next ( 30 percent), and a few examples of fireclouding ( 7 percent), where the surface was exposed to both firing atmospheres. The exterior surfaces exhibit a similar trend, with a greater occurrence of oxidized firing atmosphere (63 percent), though the reduced and fireclouded examples slightly differ with 23 percent and 14 percent, respectively. Though the trend for a greater number of oxidized fired sherds is similar to the 2005 collection, there appears to be fewer sherds exhibiting fireclouding. 


\section{Surface Finish}

The surface finish and treatments were noted on both the interior and exterior of the sherds. The majority of the sherds exhibited smooth interior and exterior surfaces ( 88 percent in both). The remaining 12 percent displayed rough surfaces, possibly intentional or due to the natural erosion occurring on the sherd.

Five sherds exhibited a black residue on at least one of their surfaces, noted as asphaltum and residue on Table B-1. The residue is most likely a result of open firing (Rice 1987:158). Two of these sherds exhibited the residue on both surfaces. Two sherds exhibited the residue on the interior surface only, while one sherd had residue only on the exterior.

Nine sherds exhibited polishing on at least one on the fragment's surfaces. Of these nine, eight are polished on both the interior and exterior of the sherd. It is possible that the polishing of the vessel surface is intentional, but it is also possible that the polishing is a result of use wear. Not enough evidence has been gathered at the Texas mission sites to determine the nature of the polished surfaces.

\section{Summary and Conclusions}

The analysis of the ceramics recovered during this excavation at Mission San Juan Capistrano found that the ceramic assemblage consisted of primarily bone-tempered earthen wares with evidence of open firing exemplified by reduced cores and oxidized surfaces. Identified vessel forms included deep bowls, jars, and shallow bowls. Surface treatments included polishing and organic residue. Average thickness falls within the range of previous Goliad wares recovered at the mission. Overall, the findings stay consistent with the previous research conducted on the native ceramics at the missions. The slight variations are possibly due to the smaller sample size used in this study and are not likely indicative of Aranama-made pottery from Mission Espíritu Santo.

\section{Construction Materials}

Because we excavated outside a historic standing structure, we expected to find artifacts associated with building materials. Construction materials are common in the artifact collection at Mission San Juan Capistrano and were found in Test Unit 1. These include items like brick, mortar, plaster, window glass, and nails. Though these artifact types often contribute to the building sequence and technology of historic structures, most of these construction materials are not datable and were found in jumbled context with modern, post-1950s trash.

The artifact distribution included mortar, nails, and glass in Levels 1 through 6 (Table 2). Flat glass, like that used in windows, was limited to the upper three levels. The machine cut nails were limited to Levels 2 and 3, while the wire nails were found in Levels 1-2 and Levels 4-5. Brick fragments were recovered from the upper two levels. Plaster was found in very poor condition from Levels 1, 2, and 4. Some other pieces of unidentified metal, too oxidized to categorize, came from the upper four levels.

\section{Bottles and Glassware}

Bottles and glassware are also common at historic sites and were expected because the compound has housed residents through the historic periods and into recent times. Room 4 is still inhabited today. Bottle glass was the most common artifact, found in Levels 1 through 6 . Those fragments that are large enough to identify are post-1950 and do not contribute to our knowledge of mission life. Some fragments of glassware were found in Levels 2, 3 and 6, but are too fragmented to identify more specifically or assign temporally. A single glass, machine-made, cat's eye marble, dating to the twentieth century was also recovered (Table 3 ).

\section{Vertebrate Faunal Remains}

\section{Barbara A. Meissner}

Before beginning an analysis of vertebrate faunal remains, especially in Colonial sites, consideration must be given to the fact that badly fragmented bone is usually unidentifiable, and is thus "analytically absent" (Lyman and O'Brien 1987). Small bones are more likely fragmented and rendered unidentifiable by non-cultural taphonomic factors (Von Endt and Ortner 1984), while large bones, especially cattle, are more likely to be fragmented from butchering (Vehik 1977). The degree to which any of these factors has affected this small collection cannot be assessed, although analysis of large collections can sometimes suggest whether the fragmentation is caused by post-depositional factors (e.g., trampling, previous disturbance, archaeological digging methods) or the result of pre-depositional cultural behaviors (see Meissner 2001:41-43). 
Table 2. Construction Materials Recovered from Test Unit 1

\begin{tabular}{|c|c|c|c|c|c|c|c|c|c|c|}
\hline \multirow[b]{3}{*}{ Level } & \multirow[b]{3}{*}{ Data } & \multicolumn{8}{|c|}{ Construction Materials } & \multirow[b]{3}{*}{ Total } \\
\hline & & \multicolumn{3}{|c|}{ Nails } & \multicolumn{4}{|c|}{ Cladding Material } & \multirow{2}{*}{$\begin{array}{c}\text { Glass } \\
\text { Flat }\end{array}$} & \\
\hline & & Cut & Wire & Tack & Brick & Mortar & Plaster & \begin{tabular}{|l|} 
Plaster/Mortar \\
\end{tabular} & & \\
\hline \multirow[t]{2}{*}{1} & Sum of Count & & 7 & & 5 & 1 & & 4 & 4 & 17 \\
\hline & Sum of Weight (g) & & & & 3.8 & 4 & & 3.9 & & 11.7 \\
\hline \multirow[t]{2}{*}{2} & Sum of Count & 1 & 1 & & 4 & 6 & & 5 & 2 & $\overline{17}$ \\
\hline & Sum of Weight (g) & & & & 2.1 & 4.5 & & 3.1 & & 9.7 \\
\hline \multirow[t]{2}{*}{3} & Sum of Count & 4 & & 1 & & 2 & & & 4 & $\overline{7}$ \\
\hline & Sum of Weight (g) & & & & & 5.5 & & & & 5.5 \\
\hline \multirow[t]{2}{*}{4} & Sum of Count & & 1 & & & 4 & 1 & & & $\overline{6}$ \\
\hline & Sum of Weight (g) & & & & & 2.3 & 0.8 & & & 3.1 \\
\hline \multirow[t]{2}{*}{5} & Sum of Count & & 3 & & & 2 & & & & $\overline{5}$ \\
\hline & Sum of Weight (g) & & & & & 2.3 & & & & 2.3 \\
\hline \multicolumn{2}{|c|}{ Grand Total Count } & 5 & 12 & $\mathbf{1}$ & 9 & 15 & 1 & 9 & 7 & 52 \\
\hline \multicolumn{2}{|c|}{ Grand Total Weight (g) } & & & & 5.9 & 18.6 & 0.8 & 7 & & 32.3 \\
\hline
\end{tabular}

Table 3. Household Items and Toys Recovered from Test Unit 1

\begin{tabular}{|c|l|c|c|c|c|r|r|}
\hline Level & Data & Bottle Glass & Dish & Molded & Unknown & Marble & Total \\
\hline 1 & Sum of Count & 12 & & & & & 12 \\
\hline 2 & Sum of Count & 12 & & 1 & 1 & 1 & 15 \\
\hline 3 & Sum of Count & 4 & 1 & & & & 5 \\
\hline 4 & Sum of Count & 3 & & & & & 3 \\
\hline 5 & Sum of Count & 2 & & & & & 2 \\
\hline 6 & Sum of Count & 1 & 1 & & & & 2 \\
\hline
\end{tabular}

Faunal remains make up the largest category of artifacts recovered from this excavation with total of 769 bones, weighing $1044.28 \mathrm{~g}$. The bone was identified to the most specific taxon possible using the comparative collection at CAR, as well as several reference texts (Balkwill and Cumbaa 1992; Boessneck 1970; Cohen and Serjeantson 1996; Gilbert 1990; Gilbert et al. 1981; Hildebrand 1955; Sobolik and Steele 1996). Identifications were conservative; bone that appeared to be cow-sized was not identified as Bos taurus unless it could be differentiated from Bison and Equus species. All bone was weighed and counted. Evidence of exposure to heat was noted on all bone. Element, portion of element, side, evidence of immaturity, butcher marks, and pathologies were noted on bone identified to the order taxonomic level. When bone identification was possible only to class, (e.g., mammal, bird) an estimate of the size of the animal was made when possible. Table 4 summarizes the taxa identified in the collection.
This sample is too small and too highly fragmented for most types of analysis to be useful, with an average bone weight of only $1.4 \mathrm{~g}$ per fragment. This is very similar to the average weight of bone recovered from similar contexts, that is, adjacent to the walls of missions. Bone from six such excavations at Missions San Juan (Meissner 2001), San José (Hunziker 1998; Meissner 1999a, 1999b) and Espada (Meissner 2000, 2004) averaged $1.7 \mathrm{~g}$. In only one case (Hunziker 1998) was the average bone weight greater than $2 \mathrm{~g}$. This represents a very high degree of fragmentation, considering that cattle dominated the identified bone in each case.

Because of the fragmentation in this collection, only 22 bones (2.9 percent), representing 13 genera, could be identified to at least the genus taxonomic level (Table 4). Only two genera, Canis (dog/coyote/wolf) and Gallus (chicken) had more than two bones identified. One complete 
Table 4. Vertebrate Taxa Identified

\begin{tabular}{|c|c|c|c|}
\hline Taxon & Common name & Count & Weight (g) \\
\hline \multicolumn{4}{|c|}{ MAMMALS } \\
\hline \multicolumn{4}{|c|}{ Artiodactyla } \\
\hline Bos taurus & Cattle & 1 & 15.89 \\
\hline Odocoileus virginianus & Whitetail deer & 2 & 18.09 \\
\hline Ovis aries & Domestic sheep & 1 & 3.08 \\
\hline Sus scrofa & Domestic pig & 2 & 5.23 \\
\hline Bovinae & Cattle or bison & 12 & $\overline{178.46}$ \\
\hline Caprinae & Sheep or goats & 1 & 0.28 \\
\hline Artiodactyla & Unidentified artiodactyla & 9 & 40.15 \\
\hline & Total Artiodactyla & 28 & 261.18 \\
\hline \multicolumn{4}{|c|}{ Carnivora } \\
\hline Canis sp. & Dog, coyote or wolf & 3 & 4.33 \\
\hline cf. Canis sp. & Dog, coyote or wolf & 1 & 2.56 \\
\hline Ursus americana & Black bear & 2 & 2.18 \\
\hline & Total Carnivora & 6 & 9.07 \\
\hline \multicolumn{4}{|c|}{ Lagomorpha } \\
\hline Sylvilagus $\mathrm{sp}$. & Cottontail rabbit & 2 & 1.43 \\
\hline & Total Lagomorpha & 2 & $\overline{1.43}$ \\
\hline \multicolumn{4}{|c|}{ Rodentia } \\
\hline Neotoma $\mathrm{sp}$. & Wood rat & 1 & 0.18 \\
\hline Sigmodon hispidus & Cotton rat & 1 & 0.54 \\
\hline Rodentia & Unidentified rodentia & 1 & 0.09 \\
\hline & Total Rodentia & 3 & 0.81 \\
\hline \multicolumn{4}{|c|}{ Unidentified Mammals } \\
\hline Mammal--small & Rabbit-sized & 3 & $\overline{0.45}$ \\
\hline Mammal--medium & Dog-sized & 2 & 0.73 \\
\hline Mammal--large & Deer-sized & 23 & 54.57 \\
\hline Mammal--very large & Cattle-sized & 143 & 454.82 \\
\hline Mammal & Size unidentified & 526 & 231.90 \\
\hline & Total Unidentified Mammals & 697 & 742.47 \\
\hline & Total Mammals & 736 & 1014.96 \\
\hline \multicolumn{4}{|c|}{ BIRDS } \\
\hline Buteo sp. & Hawk & 1 & $\overline{0.40}$ \\
\hline Gallus gallus & Domestic chicken & 3 & 1.64 \\
\hline Aves--medium & Dove-sized & 5 & 0.90 \\
\hline Aves--large & Duck-sized & 8 & 5.41 \\
\hline Aves--very large & Turkey-sized & 3 & 1.49 \\
\hline Aves & Size unidentified & 2 & 0.41 \\
\hline & Total Aves & 22 & 10.25 \\
\hline \multicolumn{4}{|c|}{ REPTILES } \\
\hline Crotalus sp. & Diamondback rattlesnake & 1 & 0.14 \\
\hline Trionyx sp. & Softshell total & 1 & 0.87 \\
\hline Testudines & Unidentified turtle & 1 & 0.67 \\
\hline & Total Reptiles & 3 & $\overline{1.68}$ \\
\hline
\end{tabular}


Stabilization of Room 4 at Mission San Juan Capistrano

Table 4, contd. Vertebrate Taxa Identified

\begin{tabular}{|c|c|c|c|}
\hline Taxon & Common name & Count & Weight (g) \\
\hline \multicolumn{4}{|c|}{ FISH } \\
\hline Ostichthys & Unidentified bony fish & 8 & 17.39 \\
\hline & Total fish & 8 & 17.39 \\
\hline & Grand Total & 769 & 1044.28 \\
\hline
\end{tabular}

canid carnassial and two fragments of another are very large, probably from a wolf. Most of the identified bone represents species very common in Colonial sites. The only exception to this is the presence of two phalanges from a black bear (Ursus americanus), one in Level 1 and the other in Level 3. Although all the epiphyses are well sealed, they appear to be small indicating the animal was young but not an infant. While black bear bones are not frequent in Colonial sites, they are occasionally found. Although limited to the mountains of West Texas today, during the Colonial period black bears were found all over the state and as late as 1854 F. L. Olmstead describes a hunter in southern Kendall County, in the hills not far north of San Antonio, who had killed 60 bears in two years (Olmstead 1962:130).

Butcher marks were not common in this collection, but this is probably the result of the extreme fragmentation. All butcher marks identified were made with metal tools, but no sawed bones were identified. Only 35 bones ( 4.6 percent) showed clear evidence of heat alteration, suggesting only incidental disposal of bone in fires.

The highly fragmented condition of this collection is common at Mission San Juan and throughout the missions in San Antonio (Hunziker 1998; Meissner 1999a, 1999b, $2000,2001,2004)$. The bone counts and weights from the seven excavated levels support the conclusion that the test unit was disturbed in all seven levels (Table 5). Slight variation in the number of bones per level indicates mixed sediments; such uniform deposition over time seems very unlikely within intact soils (Table 5).

In summary, this collection of faunal remains excavated outside Room 4 cannot serve as a reliable record of diet at Mission San Juan Capistrano. Though it represents the largest dataset collected from the test unit, the bone is too small and the matrix too mixed for conclusive statements. However, this collection is consistent with other collections from the vicinity of mission walls in San Antonio, and does confirm our understanding of mission life.

\section{Recommendations}

The single test unit excavated adjacent to the north wall of Room 4, $30 \mathrm{~cm}$ east of the chimney, revealed disturbed soils to $70 \mathrm{cmbs}$ containing a mixture of historic bone, ceramic, glass, metal artifacts and modern trash throughout the unit both horizontally and vertically. Document reviews have indicated that both archaeological and mechanical excavations have occurred across the north wall of Room 4, supporting the current archaeological findings of disturbed contexts. Therefore, construction within $1.0 \mathrm{~m}$ of the wall will not affect intact archaeological deposits. The artifacts recovered do not contribute to the integrity of this NRHPlisted site.

Many excavations have occurred over the past 75 years at Mission San Juan Capistrano with differing methodologies in pursuit of different goals. Though most reports explain the history of excavations, they do not attempt to tie excavation results together in their conclusions, the current study included. Such a task is difficult because researchers use different arbitrary levels, unit number designations, and site datums with which to record their work. The literature does not indicate the common use of the grid-system set by Schuetz and therefore no easy way to tie excavations from various projects together in the literature. Because of this, locating precisely where previous excavations have occurred and attempting to tie previous work together is difficult. CAR suggests that future consultants coordinate with NPS get the most recent site map and to locate and tie into an established site datum so that NPS can add new excavations accurately to their map. Consultants might also discuss nomenclature of unit designation with NPS so that the official site map does not have multiple excavation units with the same name like multiple Unit 1s, for example. In this report, our previous excavation map uses color-coded units tied to the archeologist's name and year of work in the legend, because we cannot change the designation of past excavation projects. However, for future work, NPS could organize all excavations under one grid system with common excavation nomenclature and excavation procedure as done at other parks 
Table 5. Vertebrate Taxa Identified, by Level

\begin{tabular}{|c|c|c|c|c|}
\hline Level & Depth (cmbs) & Taxon & Count & Weight (g) \\
\hline \multirow{8}{*}{1} & \multirow{8}{*}{$0-10$} & Ursus americana & 1 & 1.07 \\
\hline & & Artiodactyla & 2 & 10.61 \\
\hline & & Bovinae & 2 & 5.25 \\
\hline & & Mammal-large & 1 & 0.76 \\
\hline & & \begin{tabular}{|l|} 
Mammal--very large \\
\end{tabular} & 14 & 30.54 \\
\hline & & Mammal & 61 & 26.18 \\
\hline & & Aves--large & 1 & 0.38 \\
\hline & & Aves--very large & 2 & 0.66 \\
\hline & & Total & 84 & 75.45 \\
\hline \multirow{10}{*}{2} & \multirow{10}{*}{$10-20$} & Odocoileus virginianus & 1 & 9.12 \\
\hline & & Sus scrofa & 1 & 3.67 \\
\hline & & Artiodactyla & 2 & 16.81 \\
\hline & & Sylvilagus sp. & 1 & 0.99 \\
\hline & & Mammal--large & 4 & 10.68 \\
\hline & & \begin{tabular}{|l|} 
Mammal--very large \\
\end{tabular} & 29 & 93.29 \\
\hline & & Mammal & 83 & 33.62 \\
\hline & & Aves & 2 & 0.41 \\
\hline & & Trionyx sp. & 1 & 0.87 \\
\hline & & Osteicthyes & 2 & 15.35 \\
\hline & & Total & 126 & 184.81 \\
\hline \multirow{10}{*}{3} & \multirow{10}{*}{$20-30$} & cf. Canis sp. & 1 & 2.56 \\
\hline & & Ursus americana & 1 & 1.11 \\
\hline & & $\mid$\begin{tabular}{|l} 
Sigmodon hispidus \\
\end{tabular} & 1 & 0.54 \\
\hline & & Mammal--large & 6 & 21.61 \\
\hline & & Mammal--very large & 24 & 109.91 \\
\hline & & Mammal & 81 & 43.83 \\
\hline & & Gallus gallus & 3 & 1.64 \\
\hline & & Aves--large & 5 & 3.12 \\
\hline & & Crotalus sp. & 1 & 0.14 \\
\hline & & Ostichthys & 3 & 1.34 \\
\hline & & Total & 126 & 185.80 \\
\hline \multirow{14}{*}{4} & \multirow{14}{*}{$20-30$} & Bos taurus & 1 & 15.89 \\
\hline & & Odocoileus virginianus & 1 & 8.97 \\
\hline & & Bovinae & 2 & 16.37 \\
\hline & & Artiodactyla & 2 & 6.05 \\
\hline & & Canis sp. & 3 & 4.33 \\
\hline & & Sylvilagus sp. & 1 & 0.44 \\
\hline & & Rodentia & 1 & 0.09 \\
\hline & & Mammal--large & 8 & 10.91 \\
\hline & & \begin{tabular}{|l|} 
Mammal--very large \\
\end{tabular} & 15 & 40.32 \\
\hline & & Mammal & 78 & 38.38 \\
\hline & & Buteo sp. & 1 & 0.40 \\
\hline & & Aves--large & 2 & 1.91 \\
\hline & & Aves--medium & 4 & 0.69 \\
\hline & & Testudines & 1 & 0.67 \\
\hline & & Total & 120 & $\overline{145.42}$ \\
\hline
\end{tabular}


Table 5, contd. Vertebrate Taxa Identified, by Level

\begin{tabular}{|c|c|c|c|c|}
\hline Level & Depth (cmbs) & Taxon & Count & Weight (g) \\
\hline \multirow{12}{*}{5} & \multirow{12}{*}{$40-50$} & Ovis aries & 1 & 3.08 \\
\hline & & Sus scrofa & 1 & 1.56 \\
\hline & & Bovinae & 5 & 116.02 \\
\hline & & Caprinae & 1 & 0.28 \\
\hline & & Artiodactyla & 2 & 4.40 \\
\hline & & Neotoma sp. & 1 & 0.18 \\
\hline & & Mammal--medium & 1 & 0.37 \\
\hline & & Mammal--large & 4 & 10.61 \\
\hline & & Mammal--very large & 34 & 103.31 \\
\hline & & Mammal & 136 & 49.31 \\
\hline & & Aves--medium & 1 & 0.21 \\
\hline & & Osteicthyes & 3 & 0.70 \\
\hline & & Total & 190 & 290.03 \\
\hline \multirow{7}{*}{6} & \multirow{7}{*}{$50-60$} & Bovinae & 2 & 36.98 \\
\hline & & Artiodactyla & 1 & 2.28 \\
\hline & & Mammal--small & 3 & 0.45 \\
\hline & & Mammal--medium & 1 & 0.36 \\
\hline & & Mammal--very large & 25 & 67.31 \\
\hline & & Mammal & 82 & 35.93 \\
\hline & & Aves--very large & 1 & 0.83 \\
\hline \multirow{4}{*}{7} & & Total & 115 & 144.14 \\
\hline & \multirow{3}{*}{$60-70$} & Bovinae & 1 & 3.84 \\
\hline & & Mammal & 6 & 4.65 \\
\hline & & Mammal--very large & 2 & 10.14 \\
\hline & & Total & 9 & 18.63 \\
\hline & & Grand Total & 770 & 1044.28 \\
\hline
\end{tabular}

containing archaeological sites to facilitate incorporation of multiple archeological studies.

\section{Conclusion}

Excavation of one test unit east of the chimney on the north wall of Room 4 occurred to explore the depth of chimney footings and the condition and depth of the foundation. Architects and engineers examined the condition of the foundation prior to restoration of the fallen north wall and chimney. Excavations revealed bone, ceramic, glass and metal artifacts in disturbed soils to a depth of $70 \mathrm{cmbs}$. Portions of the test unit and a 40-x-40-cm expansion were excavated to $100 \mathrm{cmbs}$ in order to locate the bottom of the recent chimney footing installed in the 1980s. It was during this addition to the foundation that the disturbance likely occurred.
Artifacts recovered from the testing included numerous ceramics from the eighteenth and nineteenth centuries, fragmented animal bone, building materials, and a few glasswares. All these artifacts were discovered in the upper $70 \mathrm{~cm}$ of the test unit. None is believed to contribute to new knowledge of the mission; therefore, the Center for Archaeological Research recommends that the restoration of Room 4 proceed.

During this project, we took the opportunity to conduct a literature review of the reported archeological projects conducted at Mission San Juan Capistrano and to compile a map, table, and narrative describing the extent and placement of the units. We recommend that the NPS attempt to re-survey the extant structures of the compound and set up a site grid for all future excavators to use to facilitate comparative analysis of the archaeological data. 
We also conducted temper analysis of the Goliad ceramics to add to a larger analytical database comparing temper attributes of Goliad and Leon Plain ceramics, both native types currently distinguished only by their proximity to Spanish missions. Though the sample from Mission San Juan Capistrano is small and out of vertical context, we can be relatively sure it came from the mission grounds and contributes to the larger study undertaken by CAR addressing typology. 


\section{References Cited}

Balkwill, D. M. and S. L. Cumbaa

1992 A Guide to the Identification of Postcranial Bones of Bos taurus and Bison bison. Canadian Museum of Nature, Ottawa.

Black, S. L.

1986 The Clemente and Herminia Hinojosa Site, 41JW8: A Toyah Horizon Campsite in Southern Texas. Special Report, No. 18. Center for Archaeological Research, The University of Texas at San Antonio.

Boessneck, J.

1970 Osteological Differences Between Sheep (Ovis aries Linné) and Goats (Capra hircus Linné). In Science in Archaeology: A Survey of Progress and Research, edited by D. Brothwell and E. Higgs, pp. 331-358. Praeger, New York.

Braun, D. P.

1981 Pots as Tools. In Archaeological Hammers and Theories, edited by J. A. Moore and A. S. Neeve, pp. 107-134. Academic Press, Inc., New York.

Cardenas, Fr. M. J.

1783 Inventory of the Espiritu Santo Mission, September 27, 1783. Old Spanish Missions Research Library, Microfilm Roll 3, Our Lady of the Lake University, San Antonio, Texas.

Cargill, D. A.

1996 Stable Isotope Analysis at Mission San Juan Capistrano, San Antonio, Texas. Unpublished Master's thesis, Department of Anthropology, The University of Texas at San Antonio.

Cargill, D. A. and R. C. Robinson

2000 Archaeological Testing and Monitoring of a Service Drive at Mission San Juan Capistrano, San Antonio, Texas. Archaeological Survey Report, No. 296. Center for Archaeological Research, The University of Texas at San Antonio.

Cargill, D. A. and R. H. Hard

1999 Assessing Native American Mobility versus Permanency at Mission San Juan Capistrano Through the Use of Stable Isotope Analysis. Bulletin of the Texas Archaeological Society 70:197-213.

Carlson, S. B.

1994 Texas Beyond the Periphery: An Archaeological Study of the Spanish Missions During the Eighteenth Century. Unpublished Ph.D. dissertation, Department of Anthropology, Texas A\&M University, College Station.

Cohen, A. and D. Serjeantson

1996 A Manual for the Identification of Bird Bones from Archaeological Sites. Revised edition. Archetype Publications, London. 
Córdova, K. J., A. L. Figueroa, K. M. Ulrich, and J. M. Hunziker

2005 Archeological Testing Associated with the Stabilization of the Convento at Mission San Juan Capistrano, San Antonio, Bexar County, Texas. Archeological Report, No. 358. Center for Archaeological Research, The University of Texas at San Antonio.

Cox, I. W.

1999 Installation of Roadway Bollards at Mission San Juan Capistrano. Letter Report, No. 125. Center for Archaeological Research, The University of Texas at San Antonio.

Cox, I. W., J. J. Durst, D. D. Edmondson, B. A. Meissner, and S. A. Tomka

2001 Archaeological Investigations at Four San Antonio Missions: Mission Trails Underground Conversion Project, edited by Cynthia L. Tennis. Archaeological Survey Report, No. 297. Center for Archaeological Research, The University of Texas at San Antonio.

Escobedo, J. T.

1985 The Post-Colonial House: An Excavation Report. Mission San Juan. Manuscript on file, Center for Archaeological Research, The University of Texas at San Antonio.

Fisher, L.F.

1998 The Spanish Missions of San Antonio. Maverick Publishing Company, San Antonio, Texas.

Fox. A. A.

1993 Archaeological Testing and Monitoring in Connection with a Drainage Project at Mission San Juan Capistrano, San Antonio, Bexar County, Texas. Archaeological Survey Report, No. 217. Center for Archaeological Research, The University of Texas at San Antonio.

1999 Monitoring of Core Drilling and Testing at Missions San Juan Capistrano and San Francisco de la Espada, San Antonio, Bexar County, Texas. Manuscript on file, Center for Archaeological Research, The University of Texas at San Antonio.

Fox, A. A. and I. W. Cox

2000 Archaeological Monitoring for Exterior Lighting and Test Excavations at Mission San Juan Capistrano, Bexar County, Texas. Letter Report, No. 131. Center for Archaeological Research, The University of Texas at San Antonio.

Fox, A. A., and K. M. Ulrich

2005 Ceramics from Colonial Sites in Texas. Manuscript on file, Center for Archaeological Research, The University of Texas at San Antonio.

Francis, J. R.

1999 Temporal trends in mission populations: a comparison of pathological frequencies and long bone length at Mission San Juan Capistrano, San Antonio, Texas. Unpublished Master's thesis, Department of Anthropology, The University of Texas at San Antonio.

Gilbert, B. M.

1990 Mammalian Osteology. Missouri Archaeological Society, Columbia.

Gilbert, B. M., L. D. Martin and H. G. Savage

1981 Avian Osteology. B. Miles Gilbert, Publisher, Laramie, Wyoming. 
Gross, K. J.

1998 Archaeological Testing and Monitoring for a Proposed Drainage Channel at Mission San Juan Capistrano, San Antonio, Texas. Archaeological Survey Report, No. 283. Center for Archaeological Research, The University of Texas at San Antonio.

Habig, M. A.

1976 The Alamo Chain of Missions: A History of San Antonio's Five Old Missions. Franciscan Herald Press, Chicago.

Hildebrand, M.

1955 Skeletal Differences between Deer, Sheep, and Goats. California Fish and Game 41:327-346.

Hunziker, J. M.

1998 Faunal Analysis. In Investigations of the Southeast Gateway at Mission San José, Bexar County, Texas, by C. L. Tennis, pp. 22-26. Archaeological Survey Report, No. 252. Center for Archaeological Research, The University of Texas at San Antonio.

Ivey, J. E.

1982 Draft Report on the Archaeological Testing at the San Antonio Missions. Manuscript on file, Center for Archaeological Research, The University of Texas at San Antonio.

Ivey, J. E., M. B. Thurber, and S. Escobedo

1990 Of Various Magnificence. The Architectural History of the San Antonio Mission in the Colonial Period and the Nineteenth Century. Volume 1. National Park Service Professional Papers No. 11, Santa Fe. Manuscript on file, Center for Archaeological Research, The University of Texas at San Antonio.

Lyman, R. L. and M. J. O’Brien

1987 Plow-Zone Zooarchaeology: Fragmentation and Identifiability. Journal of Archaeological Science 16:293-317.

Meissner, B. A.

1999a Vertebrate Faunal Remains. In Archaeological Investigation of Rainwater Catchment Basins Along the South Wall of Mission San José, San Antonio, Texas, by S. A. Tomka and A. A. Fox, pp. 39-46. Archaeological Survey Report, No. 287. Center for Archaeological Research, The University of Texas at San Antonio.

1999b Vertebrate Faunal Remains. In Mission San José Repointing and Underpinning Project, San Antonio Texas, by S. A. Tomka, A. A. Fox and B. A. Meissner, pp. 35-41. Archaeological Survey Report, No. 294. Center for Archaeological Research, The University of Texas at San Antonio.

2000 Vertebrate Faunal Remains. In Archaeological Excavations of the Priest Quarters, Mission San Francisco de la Espada, 41BX4, San Antonio, Texas, by J. E. Zapata, M. J. Brown, and J. J. Durst. Archaeological Survey Report, No. 295. Center for Archaeological Research, The University of Texas at San Antonio.

2001 Vertebrate Faunal Remains (San Juan). In Archaeological Investigations at Four San Antonio Missions: Mission Trails Underground Conversion Project, edited by C. L. Tennis, pp. 32-42. Archaeological Survey Report, No. 297. Center for Archaeological Research, The University of Texas at San Antonio. 
2004 Vertebrate Faunal Remains. In San Antonio Mission Trails Statewide Transportation Enhancement Project.Construction Package 1: Archaeological Investigations at Mission San Francisco de la Espada (41BX4), City of San Antonio, Bexar County, Texas, Vol. 1, by D. A. Cargill, B. A. Meissner, and I. W. Cox, pp. 91-101. Archaeological Survey Report, No. 308. Center for Archaeological Research, The University of Texas at San Antonio.

Munoz, C. M.

2004 Native American adaptation on the Texas coastal plain: a study of the dentition from thirteen prehistoric and historic cemetery sites. Unpublished Master's thesis, Department of Anthropology, The University of Texas at San Antonio, Texas.

Olmstead, F. L.

1962 Journey Through Texas, A Saddle-Trip on the Southwestern Frontier. Original publication in 1857. Reprinted by Von Boeckmann-Jones Press, Austin, Texas.

Perttula, T. K.

2002 Native Ceramics. In Archaeological Excavations at the Last Spanish Colonial Mission Established on the Texas Frontier - Nuestra Señora del Refugio (41RF1), Refugio County, Texas, edited by C. L. Tennis, pp. 233-260. Archaeological Survey Report, No. 315, Center for Archaeological Research, The University of Texas at San Antonio. Archeological Studies Program, Report 39, Environmental Affairs Division, Texas Department of Transportation, Austin.

Rice, P. M.

1987 Pottery Analysis: A Sourcebook. The University of Chicago Press, Chicago.

Ricklis, R. A.

1995 The Ceramics of the Toyah Horizon and the Rockport Phase as Indicators of some Basic Sociocultural Patterns. Bulletin of the Texas Archeological Society 66:195-203.

1999 The Spanish Colonial Mission of Espíritu Santo (41GD1) and Nuestra Señora del Rosario (41GD2), Goliad, Texas: Exploring Patterns of Ethnicity, Interaction, and Acculturation. Bulletin of the Texas Archeological Society 70:133-168.

2000 Archaeological Investigations at the Spanish Colonial Missions of Espiritu Santo (41GD1) and Nuestra Señora del Rosario (41GD2), Goliad County, Texas. Coastal Archaeological Studies, Inc., Corpus Christi, Texas.

Schuetz, M. K.

1968 The History and Archeology of Mission San Juan Capistrano, San Antonio Texas. Vol. I. State Building Commission Archeological Program Report 10, Austin.

1969 The History and Archeology of Mission San Juan Capistrano, San Antonio Texas. Vol. II. State Building Commission Archeological Program Report 11, Austin.

1974 The Dating of the Chapel at Mission San Juan Capistrano, San Antonio, Texas. Special Report, No. 12. Office of the State Archeologist, Texas Historical Commission, Austin.

1980 The History and Archeology of the Mission San Juan Capistrano, San Antonio, Texas Excavation of the Convento. Manuscript on file, Center for Archaeological Research, The University of Texas at San Antonio. 
Scurlock, D.

1976 Archeological and Architectural Tests at Mission San Juan Capistrano Church, March and April, 1975. Special Report, No. 21. Office of the State Archeologist, Texas Historical Commission, Austin.

Scurlock, D., A. Benavides, Jr., D. Isham, and J. W. Clark, Jr.

1976 An Archeological and Historical Survey of the Proposed Mission Parkway, San Antonio, Texas. Archeological Survey Report, No. 17. Office of the State Archeologist, Texas Historical Commission, Austin.

Skibo, J. M.

1995 The Estimation of Prehistoric Values Cracked Pot Idea in Archaeology. Chapter 8 in Expanding Archaeology, pp. 92-109, edited by James Skibo, William Walker, and Axel Nielson. University of Utah Press, Salt Lake City.

Sobolik, K. D. and D. G. Steele

1996 A Turtle Atlas to Facilitate Archaeological Identifications. Fenske Companies, Rapid City, South Dakota.

Thoms, A. V., editor

2001 Reassessing Cultural Extinction: Change and Survival at Mission San Juan Capistrano, Texas, Report of Investigation, No. 4. Center for Ecological Archaeology, Texas A\&M University, College Station.

Tomka, S. A. and J. E. Zapata

20011999 Reburial at Mission San Juan Capistrano, San Antonio, Texas. Archaeological Survey Report, No. 311. Center for Archaeological Research, The University of Texas at San Antonio.

Turner, D. D.

1988 Excavations at San Juan Capistrano, 41BX5, Bexar County, Texas. Archaeological Survey Report, No. 171. Center for Archaeological Research, The University of Texas at San Antonio.

Ulrich, K. M.

2004 Merging cultures: a comparison of native and colonial ceramics from Mission San Juan Capistrano, San Antonio, Texas. Unpublished Master's thesis, Department of Anthropology, The University of Texas at San Antonio.

Vehik, S. C.

1977 Bone Fragments and Bone Grease Manufacturing: A Review of Their Archaeological Use and Potential. Plains Anthropologist 22:169-182.

Von Endt, D. W. and D. J. Ortner

1984 Experimental Effects of Bone Size and Temperature on Bone Diagenesis. Journal of Archaeological Science $11: 247-253$. 
Appendix A: Summary of Previous Investigations at Mission San Juan Capistrano 


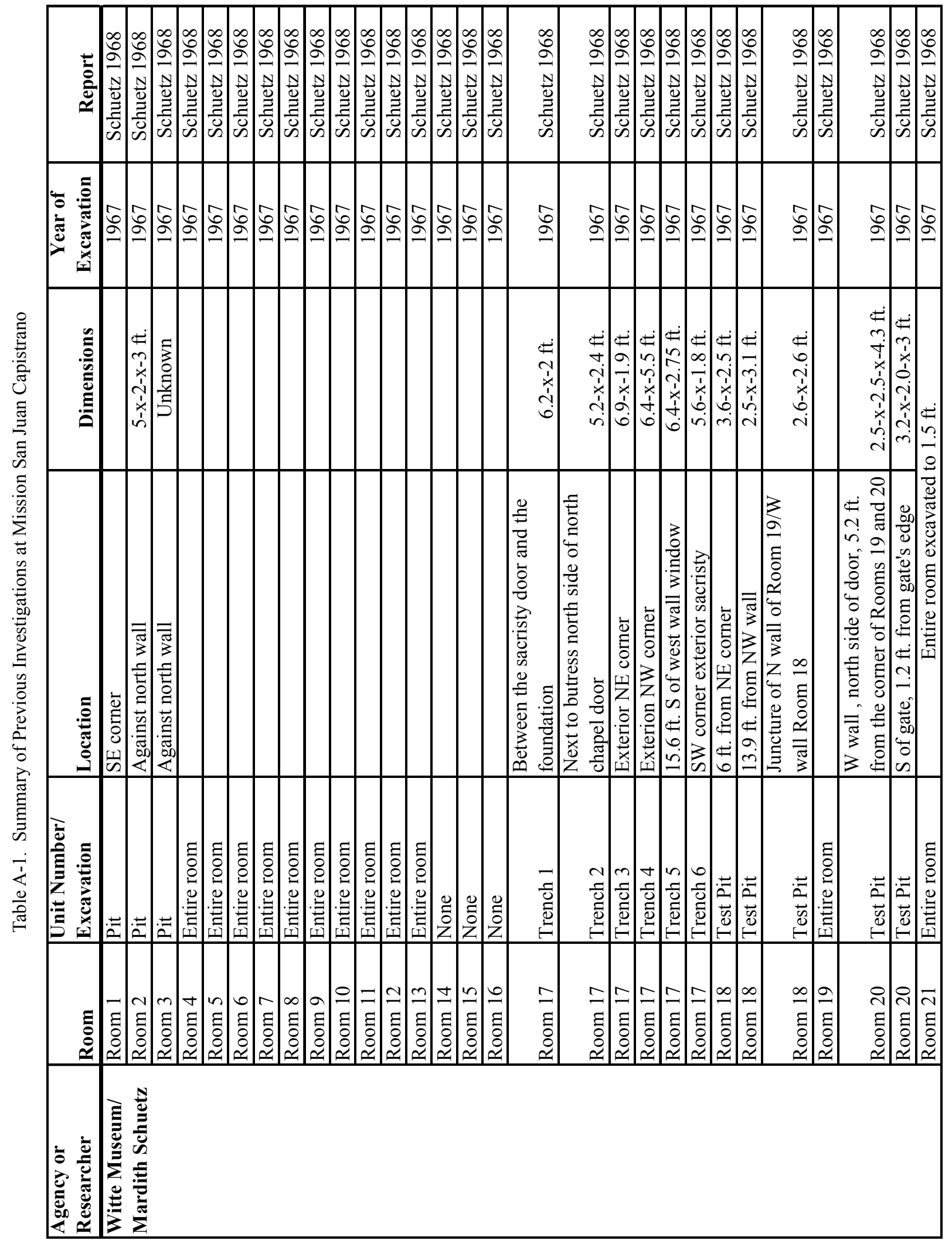




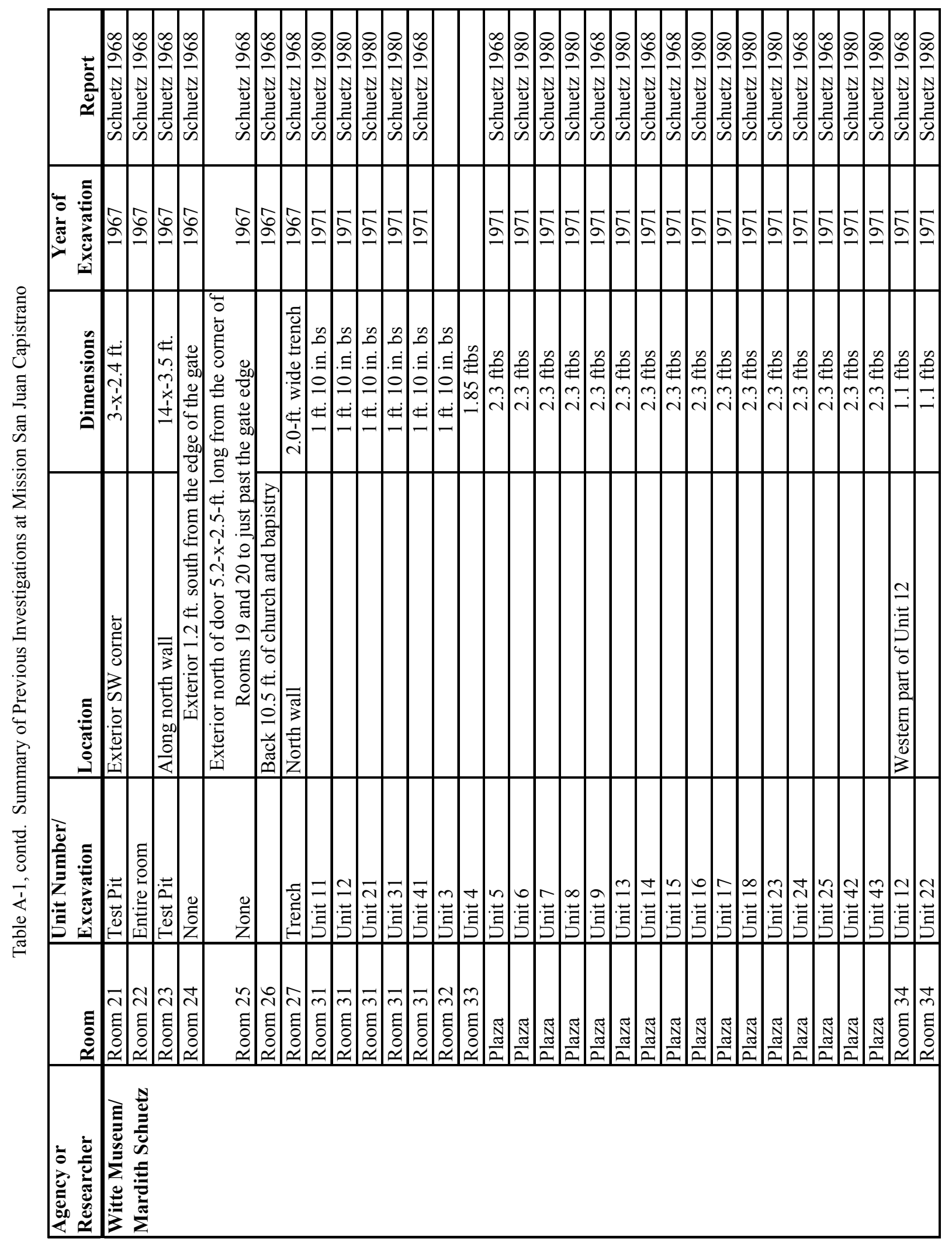




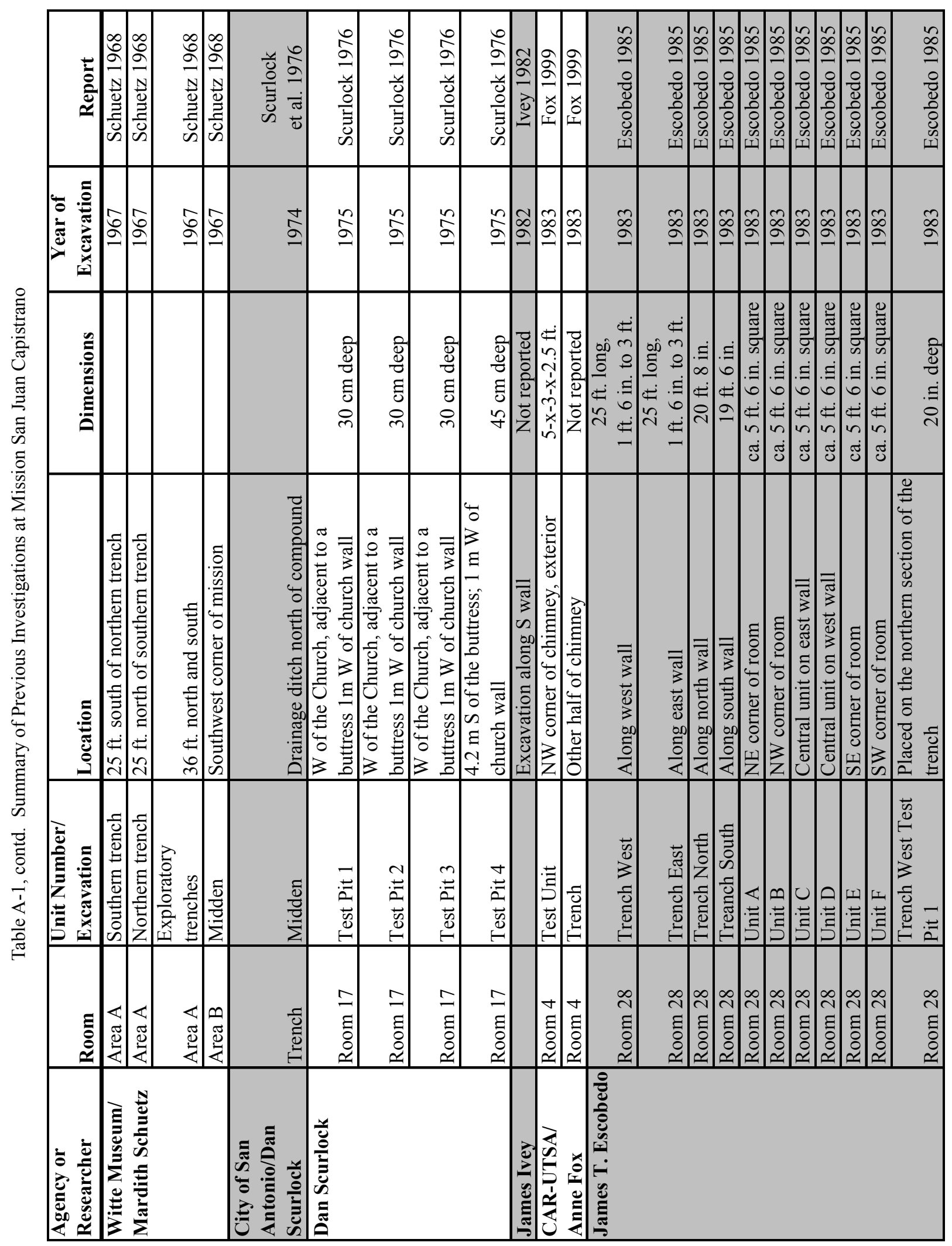




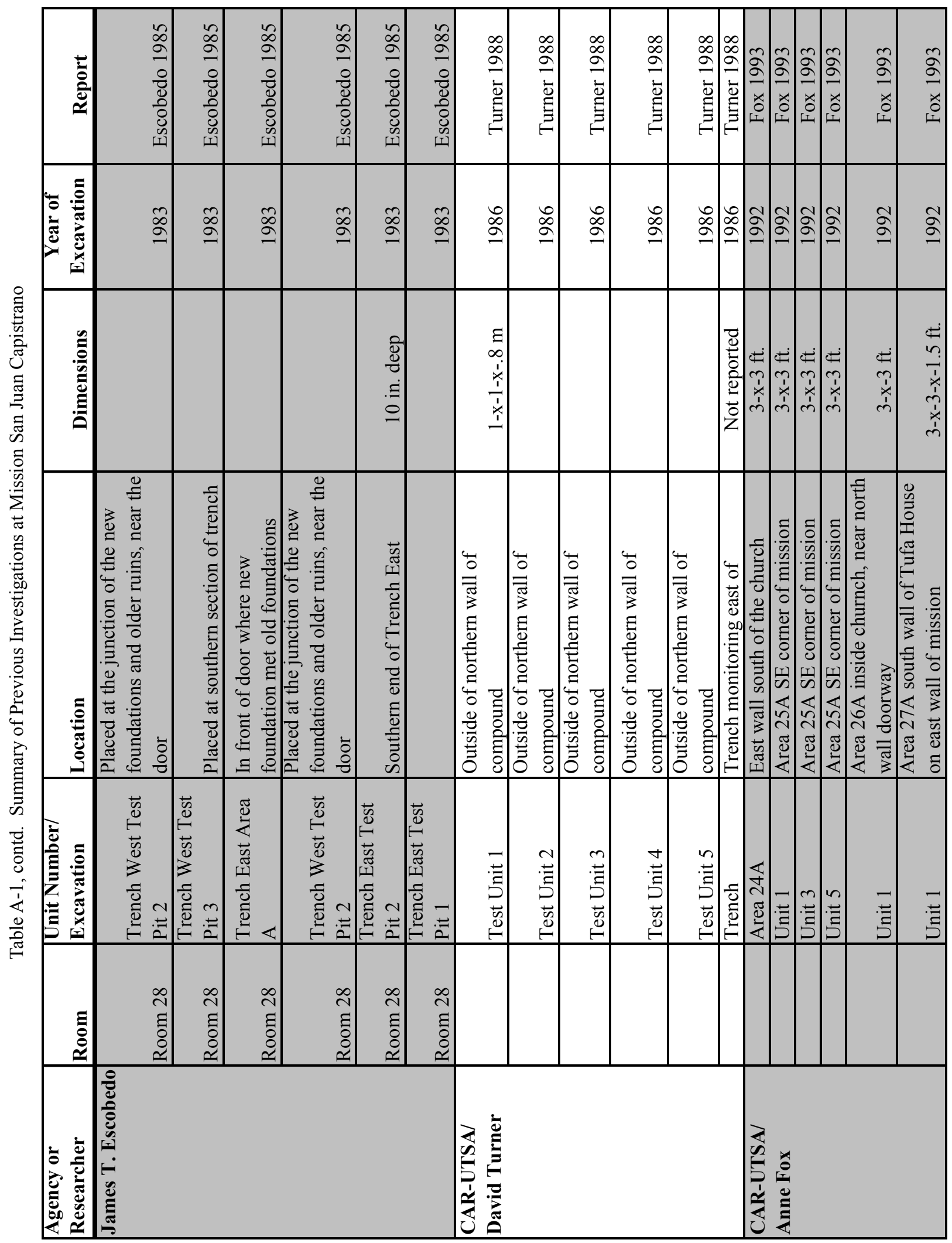




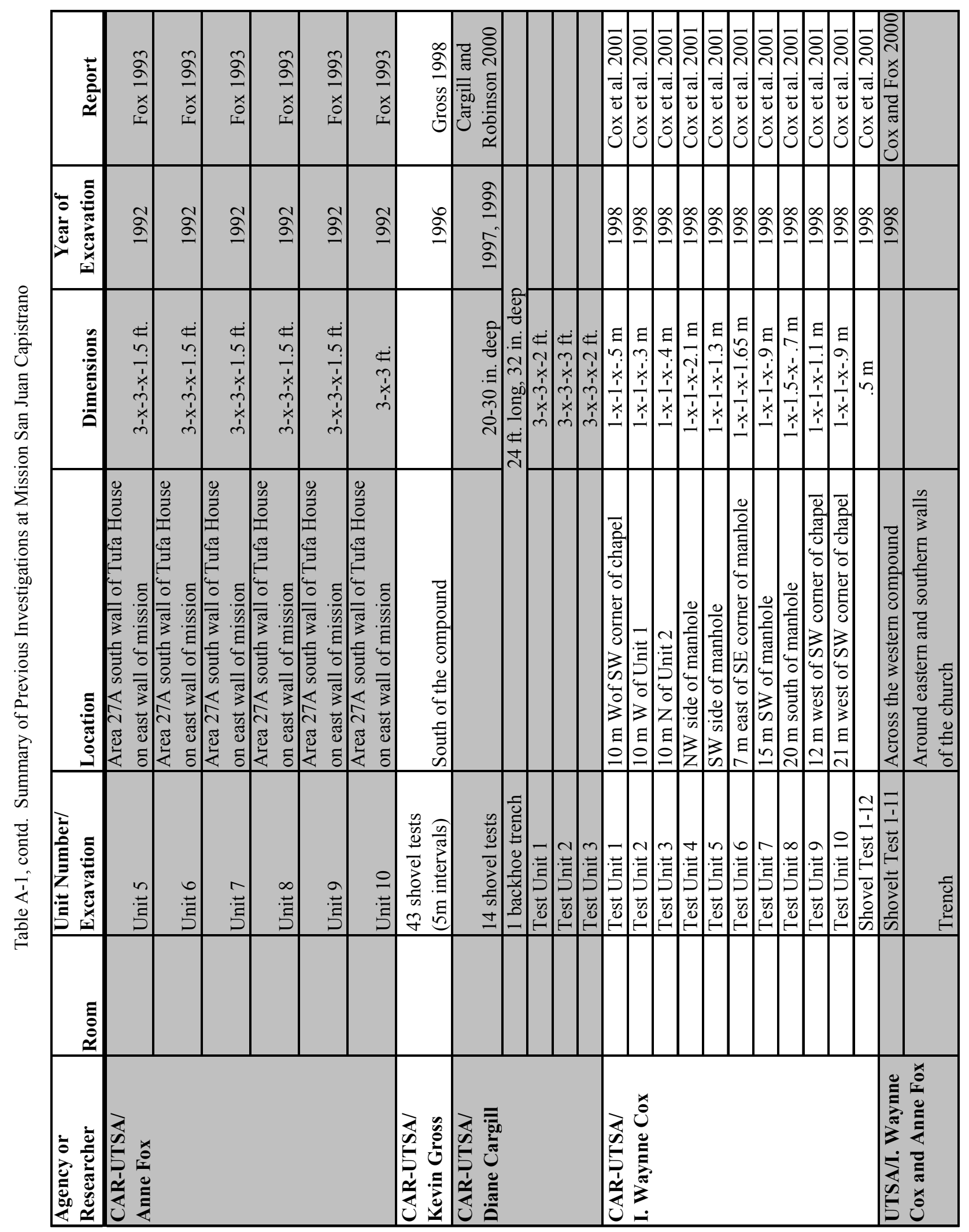




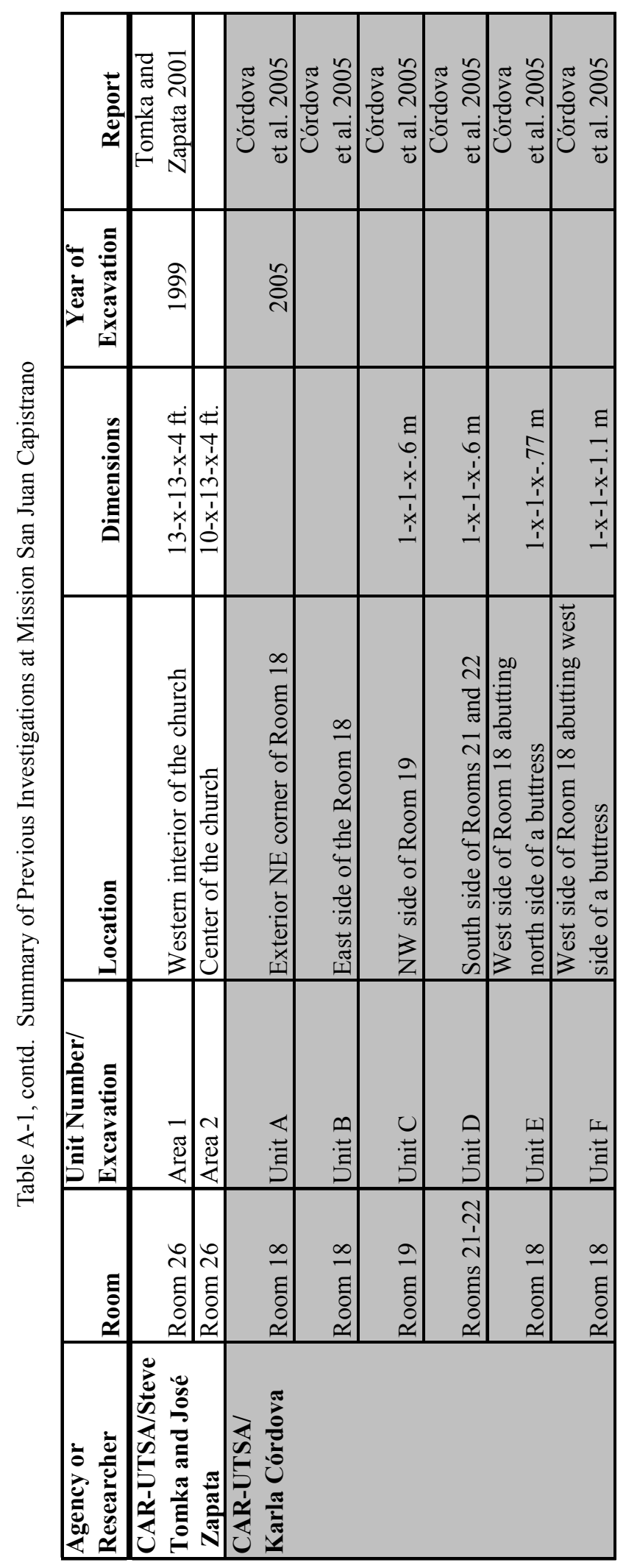


Appendix B: Summary of Goliad Ware Attributes 
Table B-1. Summary of Goliad Ware Attributes

\begin{tabular}{|c|c|c|c|c|c|c|c|c|c|c|c|c|c|c|c|c|c|c|c|c|c|c|c|}
\hline \multirow[b]{3}{*}{ Level } & \multirow[b]{3}{*}{$\begin{array}{l}\text { Specimen } \\
\text { No. }\end{array}$} & \multirow[b]{3}{*}{\begin{tabular}{|c|} 
Sherd \\
Type
\end{tabular}} & \multirow{2}{*}{\multicolumn{4}{|c|}{ Formal Attributes }} & \multirow{2}{*}{\multicolumn{6}{|c|}{$\begin{array}{ll} & \text { Technological Attributes } \\
\text { Temper }\end{array}$}} & \multicolumn{4}{|c|}{ Stylistic Attributes } & \multirow{2}{*}{\multicolumn{6}{|c|}{ Wall Thickness $(\mathrm{mm})$}} & \multirow[b]{3}{*}{ Weight (g) } \\
\hline & & & & & & & & \multicolumn{2}{|c|}{ Temper } & \multicolumn{2}{|c|}{ Firing Atmosphere } & & \multicolumn{2}{|c|}{ Surface Finish } & \multicolumn{2}{|c|}{ Decoration } & & & & & & & \\
\hline & & & | Rim Form & Lip Form & $\begin{array}{c}\text { Orifice } \\
\text { Diam.(cm) }\end{array}$ & Vessel Form & Type & Note & Density & Core & Interior & Exterior & Interior & Exterior & Interior & Exterior & 1 & 2 & 3 & 4 & & & \\
\hline & & Rim & Inverted & Round & & Shallow Bowl & Bone & & Moderate & Reduced & Oxidized & Firecloud & Smooth & Smooth & Polish & Polish & 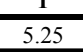 & 5.06 & 3.99 & 3.91 & 18.21 & 4.55 & \\
\hline & $\frac{2}{3}$ & $\frac{\text { Rim }}{\text { Bedv }}$ & Everted & Pointed & & & Bone & & \begin{tabular}{|l|l} 
Abundant \\
Inswa
\end{tabular} & Zoned & 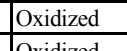 & 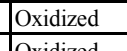 & \begin{tabular}{|l} 
Smooth \\
Shoot
\end{tabular} & Rough & None & None & 9.67 & 8.24 & 6.96 & \begin{tabular}{|c|c|}
6.09 \\
\end{tabular} & 30.96 & 7.74 & \\
\hline & $\frac{3}{4}$ & $\frac{\text { Body }}{\text { Body }}$ & & & & & $\frac{\mid \text { Bone }}{\text { Sand }}$ & & 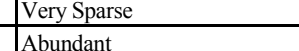 & $\begin{array}{l}\frac{\mid}{\text { Oxidized }} \\
\text { Reduced }\end{array}$ & \begin{tabular}{|l}
$\frac{\mid}{\mid}$ oxidized \\
Rexuced
\end{tabular} & 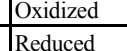 & $\begin{array}{l}\frac{\text { Smooth }}{\text { Smooth }} \\
\text { Smats }\end{array}$ & $\begin{array}{l}\frac{\text { Smooth }}{\text { Smooth }} \\
\text { Smats }\end{array}$ & \begin{tabular}{|l|l|} 
Polish \\
Asshaltum
\end{tabular} & \begin{tabular}{|l|l|l|l|l} 
Posh \\
Asphatum
\end{tabular} & $\frac{5.34}{4.49}$ & $\frac{5.65}{4.57}$ & $\frac{5.95}{4.5}$ & \begin{tabular}{|l|}
5.7 \\
4.58 \\
\end{tabular} & $\frac{22.64}{18.84}$ & $\frac{5.66}{4.61}$ & 2.7 \\
\hline & 5 & Body & & & & & Bone & Burned Bone & Moderate & Zoned & |oxidized & loxidized & $\begin{array}{ll}\text { Smooth } \\
\text { Smooth }\end{array}$ & Smooth & \begin{tabular}{|l|l} 
Polish \\
\end{tabular} & \begin{tabular}{|l|l} 
Polish \\
\end{tabular} & $\frac{4.99}{7.04}$ & $\frac{4.57}{6.16}$ & $\frac{4.3}{5.7}$ & $\frac{4.38}{6.2}$ & $\frac{18.44}{25.1}$ & $\frac{4.61}{6.28}$ & $\frac{1.6}{12}$ \\
\hline & & Body & & & & & Bone/Sandstone & & Both Sparse & Oxidized & |xidizized & Oxidized & Smooth & Smooth & Polish & Polish & 5.52 & 5.43 & 5.34 & \begin{tabular}{|c|}
5.67 \\
\end{tabular} & 21.96 & $\frac{2.20}{5.49}$ & $\frac{1.5}{1.5}$ \\
\hline & $\frac{2}{3}$ & Body & & & & & Bone & Large Chunk & 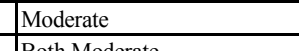 & 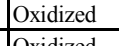 & |xidizzed & $\begin{array}{l}\text { Ooxidized } \\
\text { vilient }\end{array}$ & Smooth & Smooth & None & None & 7.12 & 7.21 & 6.51 & 7.24 & 28.08 & 7.02 & 2.3. \\
\hline & $\frac{3}{4}$ & $\frac{\text { Body }}{\text { Body }}$ & & & & & \begin{tabular}{|l|} 
Bone/Sandstone \\
Bone
\end{tabular} & Burned Bone & \begin{tabular}{|l|} 
Both Moderat \\
Abundant
\end{tabular} & $\begin{array}{l}\mid \begin{array}{l}\text { Oxidized } \\
\text { Reduced }\end{array} \\
\end{array}$ & 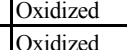 & $\begin{array}{l}\text { Oxidizized } \\
\text { Oxxidzed }\end{array}$ & $\begin{array}{l}\frac{\text { Smooth }}{\text { Smooth }} \\
\text { Smats }\end{array}$ & $\frac{\mid \frac{1}{\text { Smooth }}}{\text { Smooth }}$ & \begin{tabular}{|l|l} 
None \\
None
\end{tabular} & \begin{tabular}{|l} 
None \\
None
\end{tabular} & $\frac{5.54}{668}$ & $\frac{5.78}{6.73}$ & $\frac{6.31}{664}$ & \begin{tabular}{|l|}
5.41 \\
6.75 \\
\end{tabular} & $\frac{23.04}{208}$ & 5.76 & $\frac{2.6}{2 .}$ \\
\hline & 5 & Body & & & & & Bone & & Moderate & Oxidized & |loxidized & 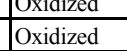 & \begin{tabular}{|l|l|l|l|l|l} 
Smooth \\
Smoth
\end{tabular} & $\begin{array}{l}\text { Smooth } \\
\text { Smooth }\end{array}$ & $\begin{array}{l}\text { None } \\
\text { None } \\
\end{array}$ & \begin{tabular}{|l|l} 
None \\
None
\end{tabular} & $\frac{6.08}{6.49}$ & $\frac{6.175}{6.19}$ & $\frac{6.64}{6.2}$ & \begin{tabular}{|l|l|}
6.32 \\
6.32 \\
\end{tabular} & $\frac{2.8 .8}{25.2}$ & $\frac{6.1}{6.3}$ & $\frac{2.5}{1.3}$ \\
\hline & & & Everted & Round & & Jar & Bone/Sand & Burned Bone & Both Sparse & & Reduced & Reduced & Smooth & Smooth & Polish & Polish & 5.12 & 3.58 & 4.57 & 5.56 & 18.83 & 4.71 & \\
\hline & $\frac{2}{2}$ & Body & & & & & Bone & Burned Bone & \begin{tabular}{|l|l|} 
Moderate \\
Iy
\end{tabular} & \begin{tabular}{|l} 
Oxidized \\
niides
\end{tabular} & \begin{tabular}{|c|c|} 
Oxidized \\
\end{tabular} & 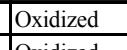 & $\begin{array}{l}\text { Smooth } \\
\text { S }\end{array}$ & Smooth & None & None & 5.1 & 5.49 & 6.21 & \begin{tabular}{|l|l|}
6.09 \\
750
\end{tabular} & 22.89 & 5.72 & \\
\hline & $\frac{3}{4}$ & \begin{tabular}{|l|l} 
Body \\
Body
\end{tabular} & & & & & \begin{tabular}{|l} 
Bone \\
Bone
\end{tabular} & Burned Rope & Very Sparse & $\begin{array}{l}\text { Oxidized } \\
\text { Oxidizad }\end{array}$ & $\begin{array}{l}\text { Oxidized } \\
\text { Oxidizad }\end{array}$ & $\begin{array}{l}\text { Ooxidized } \\
\text { Beldided }\end{array}$ & $\begin{array}{l}\text { Smooth } \\
\text { Smoth }\end{array}$ & Smooth & None & \begin{tabular}{|l} 
None \\
Some
\end{tabular} & 8.53 & $\begin{array}{l}8.56 \\
793 \\
\end{array}$ & $\frac{7.42}{819}$ & \begin{tabular}{|l|l|}
7.52 \\
0.57
\end{tabular} & 32.03 & 8.01 & 6.5 \\
\hline & $\frac{4}{1}$ & $\frac{\text { Body }}{\text { Rim }}$ & Inverted & Flat & 10 & Shallow Bowl & \begin{tabular}{|l|} 
Bone \\
Bone
\end{tabular} & Burned Bone & $\mid$\begin{tabular}{|l} 
Abundant \\
Moderate
\end{tabular} & $\begin{array}{l}\text { Oxidized } \\
\text { Reduced }\end{array}$ & 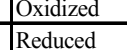 & $\begin{array}{l}\frac{R}{\text { Reduced }} \\
\text { Reduced }\end{array}$ & $\begin{array}{l}\text { Smooth } \\
\text { Smooth }\end{array}$ & $\begin{array}{l}\frac{\text { Smooth }}{\text { Smooth }} \\
\end{array}$ & $\begin{array}{l}\text { None } \\
\text { Residue }\end{array}$ & \begin{tabular}{|l} 
None \\
None
\end{tabular} & $\frac{8.49}{599}$ & $\frac{7.93}{56}$ & $\frac{8.18}{559}$ & 8.57 & $\frac{33.17}{23.7}$ & 8.29 & $\frac{1.5}{8.2}-x-1$ \\
\hline & & & Everted & Round & 14 & then sons & Bone/Sandstone & & \begin{tabular}{|l|} 
Moth Sparse \\
Both Spans
\end{tabular} & 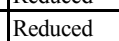 & 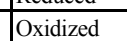 & freuncen & Smooth & $\frac{\text { Smooth }}{\text { Smath }}$ & $\frac{\text { Kestive }}{\text { Polish }}$ & \begin{tabular}{|l|l} 
Pone \\
Polish
\end{tabular} & $\frac{3.99}{7.12}$ & $\frac{3.90}{7.16}$ & $\frac{3.29}{5}$ & $\frac{0.80}{6.18}$ & $\frac{3.17}{25.46}$ & $\frac{3.93}{6.37}$ & 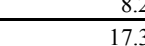 \\
\hline & 3 & Rim & Straight & Round & & Deep Bowl & Bone & & Abundant & Reduced & Oxidized & Oxidized & Smooth & Smooth & None & None & 6.188 & 6.4 & 6.68 & \begin{tabular}{|l|l|}
7.05 \\
\end{tabular} & 27.01 & $\frac{6.75}{6.75}$ & $\frac{11.3}{1.2}$ \\
\hline & 4 & Body & & & & & Bonen/Sand & & Moderate Bone/Sparse Sand & Zoned & Reduced & Reduced & Smooth & Smooth & Residue & Residue & 7.32 & 6.94 & 6.27 & & 27.06 & 6.77 & 16.5 \\
\hline & 5 & $\frac{\text { Body }}{\text { Body }}$ & & & & & \begin{tabular}{|l|} 
Bone \\
Bone/Sandtone
\end{tabular} & 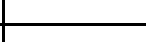 & 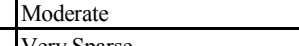 & Zoned & |0xidized & |Oxidized & Smooth & Smooth & None & None & 5.08 & 4.94 & 4.54 & \begin{tabular}{|l|l|}
.98 \\
\end{tabular} & 19.54 & 4.89 & 4.5 \\
\hline & & $\frac{\mid}{\text { Body }}$ & & & & & \begin{tabular}{|l} 
Bone \\
Bone
\end{tabular} & Burned Bone & \begin{tabular}{|l|l} 
very ypandse \\
Abundant
\end{tabular} & \begin{tabular}{|l|l|l|l|l|l|l|l|l} 
Oxidized \\
\end{tabular} & 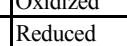 & 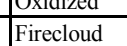 & \begin{tabular}{|l|l|l|l|l} 
Smooum \\
Smooth
\end{tabular} & \begin{tabular}{|l|l} 
Smooth \\
Smoth
\end{tabular} & $\begin{array}{l}\text { fone } \\
\text { None } \\
\end{array}$ & $\begin{array}{l}\text { None } \\
\text { None } \\
\end{array}$ & $\frac{6.76}{636}$ & $\frac{6.7}{6.64}$ & $\frac{3.125}{667}$ & \begin{tabular}{|l|l|l|}
.749 \\
\end{tabular} & 25.02 & $\frac{0.35}{6.7 .}$ & $\frac{5.1}{4.1}$ \\
\hline & 8 & Body & & & & & Bone & & Moderate & Oxidized & Firecloud & |loxidized & Smooth & Smooth & None & $\mid$ None & 6.35 & 6.57 & 6.62 & 6.79 & 26.33 & 6.58 & 4. \\
\hline & 9 & Body & & & & & Bone/Sand & & Sparse Bone/Abundant Sand & Reduced & Reduced & Reduced & Smooth & $\frac{\text { Smooth }}{\text { Smoth }}$ & $\begin{array}{l}\text { Asphaltum } \\
\text { As }\end{array}$ & None & 4.67 & 4.36 & $\frac{4.41}{4.41}$ & \begin{tabular}{|l|l|}
4.59 \\
\end{tabular} & $\frac{18.03}{18.03} \mathrm{C}(\mathrm{s}$ & 4.51 & \\
\hline & 10 & Body & & & & & Bone/Sandstone & Burned Bone & Sparse & Oxidized & |xxidized & Oxidized & Rough & Smooth & None & None & $7.67,2>3$ & 8.8 & 7.99 & 8. & 32.06 & 8.02 & \\
\hline & 11 & Body & & & & & Bone/Sandstone & & Moderate & Zoned & Reduced & Reduced & Smooth & Smooth & \begin{tabular}{|l|l|l|} 
None \\
\end{tabular} & None & 5.42 & 5.23 & $\begin{array}{l}.53 \\
\end{array}$ & 5.81 & 21.99 & 5.5 & \\
\hline & 12 & Body & & & & & Bone & & Moderate & Oxidized & Reduced & Reduced & Rough & Rough & None & None & 5.43 & 5.44 & 5.49 & 5.65 & 22.01 & 5.5 & 1.6 \\
\hline & 1 & Body & & & & & Bone/Sand & & Moderate & Reduced & Rectuced & Reduced & Rough & Rough & None & Asphaltum & 8.63 & 8.44 & 8.42 & 8.4 .4 .9$. & 33.97 & 8.49 & \\
\hline & $\frac{2}{3}$ & $\frac{y_{\text {Body }}}{\mathrm{a}}$ & & & & & Bone & & | Moderate & Reeduced & | oxidizizd & Firiecloud & Smooth & Smooth & None & None & 7.59 & $\frac{8.23}{8.237}, 0>0$ & 7.18 & 5 & 30.42 & & \\
\hline & $\frac{3}{4}, 40$ & 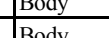 & & & & & $\operatorname{Bg} \mathrm{Jg}_{2}$ & & 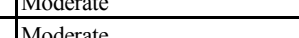 & 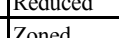 & 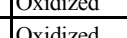 & 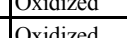 & 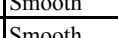 & 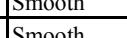 & tone & 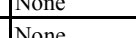 & $\frac{10.14}{57}$ & $\frac{15.07}{7001}$ & $\frac{1.23}{6.65}$ & \begin{tabular}{|l}
11.7 \\
641
\end{tabular} & $\frac{52.74}{25777}$ & 13.19 & $\frac{35}{7}$ \\
\hline & 5 & Bady & & & & & Bones/Sand & & Moderate & Reduced & Retuced & Retuced & Roumb & $\mid \frac{1}{\text { Reubh }}$ & None & None & 679 & $\frac{1.018}{608}$ & $\frac{0.05}{6.55}$ & -6 & 2677 & $\frac{6.37}{6.57}-30$ & 1. \\
\hline & 6 & Body & & & & & Bone & & Moderate & Reduced & Oxidized & Oxidized & Smooth & Smooth & None & None & $0_{6}-2>0$ & 7.46 & 7.52 & 6.678 & 28.16 & 704 & . \\
\hline & 7 & Body & & & & & Bone & Burned Bone & Abundant & Reduced & Reduced & Firiectloud & Smooth & Smooth & None & None & 7.78 & 8.07 & 7.06 & 7.25 & 30.16 & 7.54 & \\
\hline & 8 & Body & & & & & Sand & & Abundant & Oxidized & Oxidized & Oxidized & Smooth & Smooth & None & None & $-m_{2}$ & 6.51 & 6.74 & 6.85 & 26.31 & 6.58 & \\
\hline & 9 & Body & & & & & Sat & & Abundant & Ooxidized & Ooxidized & Oxidized & Smooth & Smooth & None & None & 5 & 5.08 & 506 & 5 & 204 & $\frac{51}{51}$ & 1 \\
\hline & 10 & |Body & & & & & Bo & Burned Bone & Abundant & Reduced & Reduced & Oxidizizd & Smooth & Smooth & None & None & 5.78 & 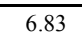 & 7.34 & \begin{tabular}{|l|l|l|}
7.54 \\
\end{tabular} & 27.49 & 6.87 & $\frac{1 .}{1.8}$ \\
\hline & 1 & Rim & 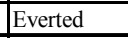 & Flat & 10 & Jar & & Bone & & Reduced & |xxidized & Oxidized & Smooth & Smooth & Polish & Polish & & 6.64 & 5.45 & & 25.32 & 6.33 & 4. \\
\hline & 2 & Body & & & & & & Burned Bone & Abundant & Reduced & |Oxidized & |Oxidized & Smooth & Smooth & None & Polish & 6.06 & 6 & 7.15 & \begin{tabular}{|c|c|} 
& \\
\end{tabular} & 26.12 & 6.53 & 2.1 \\
\hline & 3 & Body & & & & & Bone/Sandstone & & |Moderate & Zoned & Reduced & |Oxidized & Smooth & Smooth & None & None & 5.53 & - & 5.95 & 5.78 & 23.26 & 5.82 & $1 .$. \\
\hline & $\frac{4}{5},-3,4$ & body & & & & & & punned boric & |Moderate & & & |oxidized & & Smooth & & None & 6.8 & 7.06 & 6.03 3.3 & & 25.69 & & 3.4 \\
\hline & 1 & 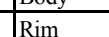 & itted & Ind & 14 & & Bonsomis & & rate & Rencuced & \begin{tabular}{|l|l|l|l|l|l|} 
Firiecloud \\
\end{tabular} & $\begin{array}{l}\text { oxidirzed } \\
\text { Oxxidized }\end{array}$ & Rowanh & Roval & None & None & $\frac{30}{6}$ & $\frac{.52}{5.52}$ & $\frac{626}{626}$ & $\frac{1.94}{594}$ & 3.72 & 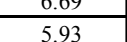 & \\
\hline & 2 & $\frac{1}{\text { Rim }}$ & Inverted & Round & $\frac{12}{12}$ & \begin{tabular}{|l|l|} 
Shallow Bowl \\
\end{tabular} & Bone & & Abundant & 吕idizized & Firecloud & Firincloud & Smonoth & $\frac{1 \text { Sugoth }}{\text { Smoth }}$ & None & |None & 5.44 & 5.15 & 5.34 & 4.72 & $\frac{20.65}{20.65}-2010$ & 5.16 & \\
\hline
\end{tabular}

